\title{
MECHANICS' LIENS AND SURETY BONDS IN THE BUILDING TRADES
}

LIENS peculiar to the building industry were established by early American legislation which has persisted, practically unchanged, to the present. Known as mechanics' liens, ${ }^{1}$ they derive from statutes drafted in an age when the typical construction project was completed by the craftsmen of a single employer. ${ }^{2}$ Today, courts must apply these statutes to a radically altered industry.

While some minor construction work is still performed by contractors who hire their own laborers and personally obtain the necessary materials, virtually all important building is now carried on by general contractors who utilize subcontractors to do a substantial part of the work. ${ }^{3}$ The development of building techniques involving a high degree of specialization has necessitated the employment of subcontractors, for the organization is rare which has at its disposal all the equipment, manpower and know-how required to complete a project of any appreciable size.

Under the subcontracting system, the owner who desires an improvement requests bids from general contractors after supplying them with plans and specifications on which to base their estimates. Once selected, the winning bidder subcontracts most of the work to other contractors with whom he has ordinarily conferred during the preparation of his estimate, and from whom he may have a contingent agreement or informal promise to perform at a given price. ${ }^{4}$ Subcontractors may in turn enter into agreements with suppliers of labor and materials or with still other subcontractors.

Undocumented material in this Comment was obtained through correspondence and discussion with people in the building trades and surety business.

1. The statutory mechanic's lien applies only to the construction industry. The lien is akin to that given by the common law to artisans upon materials in their possession for labor bestowed on them, and is a favored lien both in law and equity. See 2 KENT, Conmentaries 634 (12th ed. 1873); Peillips, Mechanics' Liens 16 (1883).

2. See note 12 infra.

3. The procedure whereby one contractor supplies all materials and services, known as "force-account" contracting, is now used primarily in building low-cost residences. A survey based on 1947 conditions revealed that only $15 \%$ of private residential building was being done by force-account contractors. Percentage figures for other significant areas were: private industrial $15 \%$, private commercial $5 \%$, public residential $0 \%$, public nonresidential 5\%, and military and naval 15\%. Colean-Newcoxib, Stabilizing ConSTRUCTTON 249 (1952). For a critical discussion of the problems posed by the lien laws in the small-project area, see Stalling, The Need for Special, Simplificd Mcchanics Lien Acts Applicable to Home Construction, 5 Law \& Contemp. Prob. 592 (1938) ; Council of State Governanents, Suggested State Legislation Program for 1957, 101 (1957).

This Comment does not treat separately problems arising on jobs where the owner himself hires all laborers and purchases all materials. Such problems are substantially similar to those here discussed.

4. A contingent contract is referred to as a "tie-up" at the time of bidding. For a general discussion of the organization of the construction industry, see CoLEAN-NEwcosm, Stabilizing Construction 90 (1952). 
Because a general contractor or subcontractor must quote his prices in advance and then attempt to perform accordingly, he may be forced by rising costs or unforseen difficulties to operate with insufficient capital. As a result, contractors are extremely sensitive to a wide variety of market and seasonal fluctuations and to risks which are beyond their control. Like the producer of any other expensive, durable goods whose purchase can be postponed, the construction industry is unable to anticipate its future volume of business with any degree of certainty. In spite of technological advances, the cost of working in bad weather is still high and the volume of construction activity diminishes markedly during the winter, thus superimposing seasonal trends on the normal year-to-year instability of the industry. ${ }^{6}$ Furthermore, radical changes in the prices of materials may occur between the time that the general contractor submits his bid and the time when he must perform. ${ }^{7}$ To avoid the costly immobilization of heavy equipment and large labor forces, building materials must be on hand exactly when required..$^{8}$ Delivery is often uncertain, however, and the materials are bulky and expensive to store. Workmen may leave a halfcompleted project to sell their services in a better market, or they may be pulled off the job during the course of a jurisdictional dispute or other union disturbance. ${ }^{0}$ Employment is seasonal, and the daily productivity of a workman is unpredictable. Death or the disability of key men in the contractor's organi-

5. For a vivid graphic illustration of the close relationship between the amount of new construction and the volume of durable goods produced, see ColeMAN-NEwcomb, STABIIzing Construction 18-19 (1952).

6. For a discussion of weather problems in the building trades, see CommriteE of tHE President's Conference on Unearployment, Seasonal Operation in the Construction INDUSTRIES (1924). Of course, many techniques for mitigating the effects of bad weather have been developed since this report was compiled, but the general picture remains essentially the same.

7. These changes are reflected in the monthly tabulations of journals such as Construction Revicw, Enginecring News Record, and Building Trade News. While labor prices have maintained a steady upward movement, prices of such essential materials as lumber, sheet metal, cement and paint fluctuate with great irregularity.

8. The high cost of an immobilized construction force can best be appreciated by reference to the hourly rates of a few of the more important trades. As of December 1957, bricklayers averaged $\$ 3.865$ per hour, carpenters $\$ 3.341$, structural iron workers $\$ 3.624$, construction machinery operators (tractors, power cranes, shovels, etc.) $\$ 3.248$. Engineering News Record, Feb. 13, 1958.

9. Disruptive union practices are widespread in the construction industry, and jurisdictional disputes still occur frequently though forbidden by statute. See $\$ 8(b)(4)$ of the Taft-Hartley Act, 61 Stat. 141 (1947), 29 U.S.C. $\S 158(b)$ (4) (1952). Disputes between the Chauffers and Teamsters Unions over whose men should drive what vehicles still cause serious delays. The Lathers and Plasterers Union's running feud with the Carpenters over who shall install acoustical ceiling tile has held up countless projects. The construction of a school in Great Neck, N.Y., was tied up for months while the Carpenters and the Laborers squabbled over which union was to unload lumber from incoming trucks. Faced with the possiblity of costly delays, job superintendents not infrequently find that the quickest way to resume work is through giving one union delegate something to ease his humiliation in having to yield to the rival union. See, e.g., Hearings Before the Special Subcomnitte of the House Committee on Education and Labor, 80th Cong., 1st Sess., 
zation, a destructive fire or some other on-the-job loss inadequately covered by insurance, bad credit judgment, dishonesty on the part of the contractor's employees, accidents and default on the part of subcontractors-all these add to the hazards of the industry.

In times of prosperity, the number of business failures tends to decrease as credit is made available for larger and more numerous projects. ${ }^{10}$ On the other hand, an excess of credit in good times often induces contractors to undertake more work than is justified by the amount of capital at their disposal. ${ }^{11}$ Hence, a contractor may find himself entangled in long-term projects which do not yield the quick return of capital necessary for meeting his obligations. If a business recession should then decrease the availability of credit and increase the likelihood of subcontractor default, the contractor may be unable to discharge his obligations and forced to abandon one or more projects. Furthermore, when a general contractor faces economic hardship, a subcontractor may prefer to default rather than to continue performance and risk nonpayment. Thus, the ability of a contractor or subcontractor to obtain interim financing can decide not only his own survival but also that of others in the subcontractual chain.

The subcontractor's financial position is inherently one of dependence, since his receipt of payment is tied to the successful performance of all those above him and, to some extent, of those below him as well.12 Conceptually, and in the absence of statute, once a general contractor defaults, an unpaid subcontractor might be able to recover from the owner in quantum meruit for the price of materials and labor supplied..$^{13}$ Nonetheless, the costs of and delays in pursuing such a remedy would render it impractical; and, of course, legal fees would diminish, and the owner's insolvency could frustrate, any recovery. Moreover, until the subcontractor had successfully litigated his claim, he would often lack sufficient capital to carry on his business.

vol. 1 (1947) (Northern New Jersey Jurisdictional Disputes in the A.F. of L. Building Trades); Haber \& Levinson, Labor Relations and Productivity in the Building TraDES 178, 230 (1956).

10. A comparison of failures over a period of years with loan prices and general business indexes establishes this fact beyond doubt. The number of business failures shows a definite correlation with the interest rate and with the general price level. See Engineering News Record, Feb. 13, 1958; U.S. Statistical Abstract 498 (1958).

11. See Backman, Surety Rate-Making 248 (1948) (graph of construction and surety activity); $i d$. at 260 (graph of losses and current liabilities in business failures); U.S. StatisTICAL ABSTRACT 498 (1957) (table of failures of construction groups); id. at 499 (table of industrial and commercial failures; table of percent of contracting firms surviving to specified age).

12. The elements of a construction project interlock like the pieces of a jigsaw puzzle. If one trade does its work improperly or fails to complete on schedule, all the trades following it will be held up, and costly repair and replacement work may be required. For example, failure to install plumbing or wiring properly may require whole walls and floors to be ripped out after a project is finished.

13. But cf. Sweeting v. Asplin, 7 M. \& W. 165, 151 Eng. Rep. 723 (Ex. 1840); Leslie \& Co. v. Metropolitan Asylums Dist., 1 Local Gov't R. 862 (C.A. 1901). 
Resort to quantum meruit has never been attempted, however, because the legislatures have provided a surer and speedier, if not exclusive, method of recovery in the form of the mechanic's lien. ${ }^{14}$ Although the product of an era in which subcontracting was uncommon and therefore originally intended to protect the prime contracting party, the mechanic's lien today serves principally to enable subcontractors and suppliers to secure payment for their services. But since the lien statutes were drafted for a purpose other than that for which they are used, their coverage is insufficient and uncertain. In addition, procedural and administrative complexities aggravate the statutes' inadequacies.

One result of these inadequacies has been the emergence of the corporate surety as a supplementary guarantor of payment and performance. ${ }^{15} \mathrm{Com}-$ pulsory bonding obtains at present on all federal and most state projects, and on some private work as well. ${ }^{16}$ Because the solvency of the corporate surety is virtually assured by statute and by the self-regulation of the surety business, ${ }^{17}$ adequately bonding a contractor can eliminate any need to resort to the owner's property by way of the lien statutes. In brief, bonding provides an alternative to mechanics' liens as a method of protecting subcontractors and suppliers from the manifold risks of the construction industry. The relative merits of bonding and mechanics' liens form the basis of this Comment.

\section{Mechanics' Liens}

A mechanic's lien is, essentially, the right of a builder to seek a judicial sale of the owner's property in order to satisfy unpaid claims. All statutes dealing with privately owned construction provide that the lien attaches to the improvement and, in varying degrees, to the land on which it stands. ${ }^{18}$ So long as the lienor remains unpaid, he is entitled to the security afforded by the property; consequently, he may institute foreclosure proceedings and, along with other lien

14. The first mechanics' lien legislation in the United States was passed in response to demands by the commission in charge of building Washington, D.C., and by Thomas Jefferson and James Madison in particular. Rocker, MECHanics' Lrens 1 (1909). For this first lien statute, see Md. Acts 1791, ch. 45, § 10. No similar legislation existed in England at the time, nor has any been enacted since. See, e.g., Phillips, Mechanics' LIENs 4 (1883). The French, however, have provisions similar to the mechanics' lien acts. French Cruil Code, art. 2103 (Cachard 1930).

15. For a general discussion of the growth of the surety industry, see BackMan, SuRety RATE-Míaining 1 (1949).

16. Almost all states and many municipalities require payment and/or performance bonds on public works. For digested tabulation; see CRedit MANUal of Conmercial LAws 583 (1958) and notes 136-39 infra. In addition, the general contractor is usually required to accompany his bid with a deposit or bond to guarantee that, if selected, he will undertake the work awarded. See Rhyne, Municipal Contracts 53 (1952).

17. See generally Crist, Corporate Suretyship 52 (1939); Lunt, Surety Bonds 13 (1922).

18. E.g., Iowa Code ANn. $\S 572.2$ (1946) ; N.Y. LIEN LAw §§ 3, 4 (Supp. 1958); PA. Stat. ANN. tit. 49, $\$ 21$ (Supp. 1957). For a summary of all the state statutes, see Credit Mlanual of Comisercial Laws 592 (1958). 
claimants, share in any resulting distribution of proceeds. ${ }^{19}$ The owner can frequently discharge the lien by depositing a bond or sufficient cash with the court. $^{20}$ The available fund is then distributed among the lienors in such fashion as the court may deem proper. Ordinarily, no personal liability for any deficiency is imposed on the owner unless, of course, he was a party to the contract under which the claim arose. ${ }^{21}$

\section{Computing the Lienable Clain}

The value of a given mechanic's lien will depend in large measure on the state law under which the claim arises. Roughly speaking, the statutes may be divided into two general groups-the New York and the Pennsylvania types.

The New York Category. In New York, the subcontractor's lien is limited to that part of the contract price due and owing to the general contractor from the owner at the time that the notice of lien is given, plus any amount which may become due thereafter. ${ }^{22}$ Thus, to recover a given sum, a subcontractor

19. See, e.g., Ariz. Cone ANn. § 62-214 (1939); N.J. Stat. Ann. \$ 2A :44-97 (1953); N.Y. LIEN LAw $\$ 41$. In New Jersey, however, the owner may cut of the right of lien as against everyone but the general contractor by timely filing of the building contract and specifications in the county clerk's office. Suburban Lumber Co. v. Gerber, 17 N.J. Super. 33, 85 A.2d 275 (App. Div. 1951). The unpaid materialman or subcontractor must then proceed by "stop notice," filing notice of nonpayment in the county clerk's office, together with actual notice to the owner of the claim. N.J. STAT. ANN. \$ 2A :44-75-\$6 (1953). Stop notice operates as an assignment to the claimant, pro tanto, of the debt (if any) due from the owner to the contractor. See, e.g., Commonwealth Roofing Co. v. Riccio, 81 N.J. Eq. 486, 87 At1. 114 (Ct. Err. \& App. 1913). This procedure has the effect of substantially delaying progress payments, particularly where claims have been exaggerated. The comparable procedure in New York involves paying a fund into court or the posting of a bond. See note 20 infra.

20. E.g., N.Y. Lien Law $\$ \S 20,37$; Iowa Code ANn. $\$ 572.15$ (1949); Tex. Rev. Civ. Stat. Ann. art. 5472b-1 (Supp. 1958).

21. See note 37 infra and accompanying text. Nor may the claimant bring a personal action against the owner. See, e.g., Palmer v. Apperson, 70 Ariz. 35, 215 P.2d 1020 (1950); Gignilliat v. West Lumber Co., 80 Ga. App. 652, 56 S.E.2d 841 (1949).

22. N.Y. Lien Law $\$ 4$ (Supp. 1958). Dempsey v. Mít. Sinai Hosp., 186 App. Div. 334, 174 N.Y. Supp. 386 (1919) ; Szemko v. Weiner, 176 App. Div. 620, 163 N.Y. Supp. 382 (1917); McMillian v. Seneca Lake Grape \& Wine Co., 5 Hun. 12 (Nassau County Ct. 1875), rev'd on other grounds, 67 N.Y. 215 (1876) (discussing the form of the lien right in terms of equitable subrogation). For modern cases applying the mechanics" lien doctrine, see Owens v. Ebner, 74 N.Y.S.2d 169 (Sup. Ct. 1947) ; Nassau Suffolk Lumber \& Supply Corp. v. Bruce, 177 Misc. 825, 31 N.Y.S.2d 906 (Sup. Ct. 1941). modified, 265 App. Div. 879, 38 N.Y.S.2d 73 (1942). In the latter case, by the terms of the general contract, the owner was to pay the general contractor in accordance with cash advances made by a bank under a financing agreement with the owner. The bank subsequently refused to make the advances because the building did not meet the requirements of the agreement. As nothing was therefore due to the general contractor, the court held that there was no fund on which to predicate a materialman's lien.

The amount-due limitation exists in nineteen other jurisdictions: ALA. CODE ANN. tit. 33, § 37 (1940) (defeasible by notice); Conn. Gen. Stat. $\$ 7220$ (1949); D.C. Core Ann. § 38-104 (1951); Fla. Stat. Ann. \& 84.02-.05 (1943); Ill. Rev. Stat. ch. \$2, \$ 21 
must show that at least the amount of his claim was owing to the general contractor. And the owner generally may not be compelled to pay more than the contract price. ${ }^{23}$ If the general contractor underbid the job, or if costs rose unexpectedly during the course of the work, claims may exceed the amount due, the excess constituting an unrecoverable loss which must be borne by the general contractor, subcontractors and suppliers. ${ }^{24}$ If the general contractor defaults after completing the work and receiving payment in full, the loss usually will fall on the subcontractors and suppliers alone.

Because the owner is not liable to lienors for amounts which he has paid the general contractor before any liens are filed, ${ }^{25}$ he can periodically reimburse the general contractor with impunity on the basis of reports of work accomplished. The New York type statute thus allows the owner to provide the general contractor with a steady flow of cash which diminishes the latter's need to borrow in order to meet his obligations to the subcontractors. Ordinarily, the owner secures himself against nonperformance by retaining a certain percentage of the amount payable each period; the general contractor receives these percentages after the project has been satisfactorily completed. ${ }^{26}$ Of course, a general contractor can reduce his need for interim financing if he overreports the amount of work finished during the initial stages and thereby actually draws

(1957) ; LA. Civ. Code Ans. art. 2772 (1951) ; Mass. Ans. Laws. ch. 254, § 4 (1956); Mirss. Code Ann. $\$ 372$ (1942); N.H. Rev. Stat. Ann. ch. 447, \$§ 5, 6 (1955) ; N.J. Stat. AnN. \$ $2 A: 44-78$ (1951); Nev. Rev. Stat. \$ 108.050 (1956); N.C. Gen. Stat. ANN. $\$ 44-6$ (1949) ; S.C. Code ANN. \$ 45-254 (1952) ; S.D. Code \$§ 39.0701, .0703 (1939); Tex Rev. Civ. Stat. Ann. art. 5461 (Supp. 1958) ; Utan Code ANn. $\$ 38-1-22$ (1953); Vt. Stat. \$ 2754(II) (1947); VA. CODE ANN. § 43-7-8 (1950).

23. "If labor is performed for, or materials furnished to, a contractor or subcontractor for an improvement, the lien shall not be for a sum greater than the sum earned and unpaid on the contract at the time of filing the notice of lien, and any sum subsequently earned thereon." N.Y. LIEN LAw § 4. See Herrmann \& Grace v. Hillman, 203 N.Y. 435, 96 N.E. 741 (1911); Brainard v. County of Kings, 155 N.Y. 538 (1898). But see Richman v. City of New York, 89 Misc. 213, 151 N.Y. Supp. 744 (Sup. Ct. 1915) (maverick decision).

24. Underbidding occurs frequently. Often it may be the result of a wholly speculative estimate by a subcontractor whose quotation was obtained during the estimating period and who then refuses to perform. Costs may rise after the contractor deliberately avoided tie-ups, see note 4 supra, in the hope that costs would decrease by the time he eventually made his subcontracts or material purchases. The frenzy of trying to meet a bid deadline, much less competition, has produced odd results. Errors in general contractors' estimating departments include failure to make provision for whole floors, walls and partitions, and the analysis of two-way streets as though they were one lane. Further, unforeseen conditions at the job site may materially increase costs. The discovery of rock or water where easy excavation had been expected, either because of faulty borings or sheer wishful thinking, can add tremendous expense.

25. In some jurisdictions, including New York, a lien is binding on the owner only if he is subsequently served with notice. E.g., N.Y. IIEN LAw $\$ 11$; Ill. REv. Stat. ch. 82, $\$ 24$ (1957); Mo. Ann. Stat. $\$ 429.100$ (1951). Cf. Ind. Stat. Ann. $\$ 43-709$ (1952) (personal liability of owner).

26. Retained percentages are required on state jobs in New York. N.Y. STAte Fin. LAw $\$ 139$ (Supp. 1958). On private work, the average is $10 \%$, though retained amounts may occasionally be as high as 15 or $20 \%$. 
down payments equivalent to or in excess of the full value of his services. Since overreporting is apparently a common practice, the objective underlying retained percentages is often defeated.

The general rule-that the owner is not liable for amounts paid the general contractor before a lien is filed ${ }^{27}$-does not embrace payments which are fraudulent as to subcontractors or suppliers. If the owner pays the general contractor in a deliberate attempt to defeat a lienor's claim, the payment will be held not to reduce the "amount due" for the purpose of computing the total sum of liens allowable. ${ }^{28}$ Although the cases have not defined fraud with any degree of precision in this context, they indicate that deviations from an existing schedule which serve a bona fide business purpose are permissible. ${ }^{28}$

The Pennsylvania Category. Under laws like Pennsylvania's, a subcontractor may lien for the full value of his claim irrespective of the amount due the general contractor. ${ }^{30}$ Because the general contractor is considered the owner's agent for the hiring and directing of those who actually perform most of the construction work, ${ }^{31}$ the subcontractor's right to lien is said to be "direct" rather

27. The owner also may not be liable if he has not received notice. Note 25 supra.

28. N.Y. Lien Law \& 7; Glens Falls Portland Cement Co. v. Schenectady County Coal Co., 163 App. Div. 757, 149 N.Y. Supp. 189 (1914), modifying 83 Misc. 552, 144 N.Y. Supp. 519 (1913) ; Maycumber v. Wolfe, 10 Misc. 2d 464, 171 N.Y.S.2d 44 (Sup. Ct. 1958) ; N.J. Stat. Ann. 2A:44-85 (1951); Hasson v. Bruzel, 104 N.J. Eq. 95, 144 Atl. 319 (Ch. 1929) ; cf. J.D. Loizeaux Lumber Co. v. Steinberg, 102 N.J.L. 15, 131 Atl. 131 (Sup. Ct. 1925).

29. See Wagner v. Butler, 155 App. Div. 425, 140 N.Y. Supp. 50 (1913) ; cf. Rosenbaum v. Paletz, 114 N.Y. Supp. 802 (App. T. 1909) ; J. W. Van Cott \& Son v. Gallon, 163 Misc. 914, 298 N.Y. Supp. 67 (Delaware County Ct. 1937).

If a general contractor's default is imminent and costs of completion are high, the owner may decide to give the sinking contractor extra financing to avoid the losses in both time and money involved in reletting the project. The extra financing, though nonfraudulent, might be deemed an "amount due." $C f$. Cosmopolitan Mut. Cas. Co. v. Monarch Concrete Corp., 6 App. Div. 2d 163, 176 N.Y.S.2d 122 (1958).

30. PA. Srat. Ans. tit. 49, \& 21 (1930) ; Bryan v. Stempkowski, \&8 Pa. Super. 390 (1926). The following jurisdictions adhere to the Pennsylvania rule. ArIz. CodE Ans. \$ 62-201 (1939); Ark. Stat. Ann. \$ 51-601 (1947); Cal. Civ. Proc. Cone \$ 1183.1 (1955); Colo. Rev. Stat. AnN. § 86-3-1 (1953); Del. Code Ann. ch. 25, § 2702 (1953); GA. Code Ann. § 67-2001 (1935) ; Idaho Code Ann. § 45-501 (Supp. 1957); Ind. Stat. Ann. $\$ \S 43-701,-713$ (1952) ; Iowa Code Ann. $\$ 572.5$ (1946) ; Kan. Gen. Stat. AnN. $\$ \$ 60-$ 1401, -1403 (1949) ; Ky. Rev. Stat. Ann. \$ 376.040 (1955) ; Me. Rev. Stat. Ann. ch. 178, § 34 (1954) ; MD. Ann. Code art. 63, § 1 (1957) ; Mich. Stat. Ans. § 26.281 (Supp. 1957); Minn. Stat. Ann. \& 514.01 (1946); Mo. Ann. Stat. $\$ 429.010$ (1949); Mont. Rev. Codes Ann. § 45-504 (1947); Neb. Rev. Stat. Ann. § 52-102 (1952); N.M. Stat. Ann. \$\$ 61-2-2, -6 (1953); N.D. Rev. Code § 35-120 (1943) ; OKLA. Stat. AnN. tit. 42, $\S 143$ (1951) ; Ore. Rev. Stat. \$ 87.065 (1957); Onlo Rev. Cone AnN. § 1311.02 (Page 1953); R.I. Gen. Laws Ann. ch. 34, § 28-1-21 (1952); Tenn. Cone Ann. $\$ 64.1102$ (1956); Wash. Rev. Code Ann. $\$ 60.04 .110$ (1951); W. VA. Code Ann. $\$ 3722$ (1955); Wis. Stat. \$ 289.02 (1955); Wyo. Comp. Stat. Ann. \$ 55-201 (1945).

Under the Iowa code, if the lienor fails to file within the statutory period, an "amount due" limitation takes effect. Iowa CODE ANN. \$ 572.11 (1946).

31. See, e.g., Prince v. Neal-Millard Co., 124 Ga. 884, 53 S.E. 761 (1906); Weeter Lumber Co. v. Fales, 20 Idaho 255, 118 Pac. 289 (1911); Pittsburgh Plate Glass Co. v. Leary, 25 S.D. 256, 126 N.W. 271 (1910). 
than "derivative." 32 Payments to the general contractor prior to the filing of a lien therefore do not diminish the owner's total liability. ${ }^{33}$

In some states with this type of statute, the total of recoverable liens may not exceed the contract price. ${ }^{34}$ Unless, however, the owner is able to withhold all payments to the general contractor until the period for the filing of liens has expired, a provision limiting the aggregate of liens to the contract price does not make that price the measure of the owner's actual liability, since he receives no credit for prior payments to the contractor. For this reason (among others), some jurisdictions permit an owner who posts an appropriate bond, or who publicly files the construction contract, to restrict his liability either to the amount due or to the unpaid balance of the contract price. ${ }^{35}$ Absent such a procedure, an owner may be forced to satisfy liens which, when added to payments on the contract, exceed the contract price. Theoretically, he may then sue the general contractor for the excess, but this right is likely to be worthless because the general contractor is usually insolvent at this point. ${ }^{36}$

Viewed superficially, the owner's liability would appear to be limited to the foreclosure value of the lienable property, for deficiency judgments are rarely awarded in this area. ${ }^{37}$ Actually, however, when the amount of lien claims is

32. E.g., Baker Sand \& Gravel Co. v. Rogers Plumbing \& Heating Co., 228 Ala. 612, 154 So. 591 (1934) ; cf. Hamilton v. Means, 155 Pa. Super. 245, 38 A.2d 528 (1944).

33. Pa. Stat. Ann. tit. 49, $\$ 21$ (1930); see Bryan v. Stempkowski, $88 \mathrm{~Pa}$. Super. 390 (1926); Better Roofing Materials Co. v. Sztukovski, 183 S.W.2d 400 (Mo. Ct. App. 1944); cf. Florida Fruit Co. v. Shakelford, 145 Fla. 216, 198 So. $\$ 41$ (1941).

34. See Ga. Code Ann. § 67-2001(2) (1933); Kan. Gen. Stat. Ann. § 60-1403 (1949) ; Ky. Rev. Stat. AnN. \$ 376.010 (1955); Mich. Stat. Anv. § 26.281 (Supp. 1957); Minn. Stat. AnN. § 514.03 (1946); N.D. Rev. Code § 35-1207 (1943); Onio Rev. Code Anv. § 1311.05 (Page 1953); Orla. Stat. Ann. tit. 42, 143 (1938); Tenn. CODE ANN. § 64-1120 (1955).

35. Pennsylvania law provides that if the contract between owner and general contractor stipulates for periodic payments and either is filed in the prothonotary's office before work is commenced or is brought to the attention of the subcontractors and suppliers prior to their furnishing services or materials, lien claims will be limited to the balance of the contract price remaining unpaid at the time the liens are filed. Under this provision, a court would stay all executions on judgments recovered on lien claims. By paying the whole balance found due into court, the owner could then have the lien claims stricken. PA. Stat. Ann. tit. 49, \& 76 (1930). The paucity of annotations and reported cases on this provision indicate that it is infrequently invoked.

In many states, the owner may limit his liability to the "amount due" by posting an appropriate bond prior to the commencement of the work. See, e.g., CAI. CIV. Proc. CODE § 1185.1 (c) (1955), Roystone Co. v. Darling, 171 Cal. 526, 154 Pac. 15 (1915) ; CoLo. Rev. Stat. Ans. § 86-3-2 (1953) ; Munroe v. Merrell, 113 Mich. 491, 71 N.W. 850 (1897); N.Y. LIEN LAw § 37 (Supp. 1958); National Gás Co. v. Ada Iron \& Metal Co., 185 Otla. 415, 93 P.2d 529 (1939); W. VA: Code ANN. § 3743 (1955), Atlas Powder Co. v. Nelson \& Chase \& Gilbert Co., 124 W. Va. 298, 20 S.E.2d 890 (1942).

36. For the right of recovery over, see, e.g., ALA. CODE ANn. tit. 33, § 57 (1940). See generally 5 Corbin, Contracts $\$ \$ 1089-94$ (1950).

37. In most jurisdictions, the question of deficiency judgments has not arisen. Only three states expressly permit a mechanics' lienor whose claim is not satisfied by sale of the property to go against the owner personally for the deficiency. PA. STAT. ANn. tit. 
large, the owner is forced to choose between two equally unpromising possibilities. He must either pay the claims-which may swell the total cost of construction far beyond the original contract price-or else he must allow the lienors to foreclose-thus forfeiting not only the property but also its future use. Furthermore, on surrendering the project, he may have to respond in damages to its prospective tenants. In resolving his dilemma, therefore, the owner must compare the price of paying the liens with the cost of forfeiture, that is, with the total anticipated losses resulting from his failure to finish the project plus the value of his actual equity in the property and the improvement.

Owners who are subjected to the comparatively large lien claims permitted under the Pennsylvania type of statute will ordinarily either require that general contractors be adequately bonded, or will deal only with those who are heavily capitalized. When the latter approach is chosen, successful competition by small firms may be less common than in jurisdictions like New York. And by discouraging payments during the course of a project, the Pennsylvania type statute impedes the acquisition of funds which general contractors require. ${ }^{38}$

Some Pennsylvania type jurisdictions go so far as to grant the owner immunity from any contractual claims of the general contractor until the period during which other claimants may file their liens has elapsed.39 Since the statutory period for filing by the last workman on the job does not start to run until construction is completed, the owner who seeks to limit his total lien and contract liability to the contract price will withhold all payments until some time following the termination of work. Consequently, general contractors in these states are forced to depend entirely on their own capital and outside loans to finance building projects.

12, $\$$ 2621.1-.11 (1951), Hoffman Lumber Co. v. Mitchell, 170 Pa. Super. 326, 95 A.2d 664 (1952) ; Ilr. Rev. Star. ch. 82, \$ 19 (1957) ; Minn. Stat. Ann. \$\$ 514.15, 581.09 (1946) ; cf. Smude v. Amidon, 214 Minn. 266, 7 N.W.2d 776 (1943). Some states, on the other hand, have emphatically rejected such deficiency actions. Chambers Lumber Cu. v. Gilmer, 60 Ga. App. 832, 5 S.E.2d 84 (1939); GA. CoDE ANn. § 67-2001 (1933); Jackson v. J. A. Franklin \& Son, 107 Ind. App. 38, 23 N.E.2d 23 (1940); Ind. Stat. Ans. § 43-709 (1952) ; Paulsen v. Western Elec. Co., 67 Okla. 309, 171 Pac. 38 (1918). If, however, direct contractual liability has accrued simultaneously with the lien, deficincy: recovery against the owner is allowed. E.g., Ridens v. Economy Home Builders, 104 Cal. App. 677, 286 Pac. 481 (Dist. Ct. App. 1930) ; Moody-Seagraves Ranch v. Erown, 69 S.W.2d 840 (Tex. Civ. App. 1934).

38. Despite these theoretical distinctions, states which follow the Pennsylvania type of lien system seem to show only slightly larger losses incurred on contractor failures than do states of the New York category. For example, in the middle Atlantic states (New York, New Jersey, Pennsylvania, Maryland, Delaware and District of Columbia), failure loss in 1956-1957 was $0.5 \%$ of total construction value. Here, the New York system obtains except in Pennsylvania, which accounted for $21 \%$ of total construction. For the same period in the far western states (California, Oregon, Washington, Idaho, Nevada, Utah, Arizona), failure loss was $0.8 \%$ of construction. There, the Pennsylvania system obtains except in Utah, which accounted for $3 \%$ of the total construction. These figures are derived from Engineering News Record, Feb. 13, 1958.

39. E.g., Iowa Code Ann. $\$ 572.13$ (1950) ; Kan. Gen. Stat. Ann. $\$ \S 60-1401,-1403$ (1949); Okla. Stat. Ann. tit. 41, § 143 (1951). 


\section{Subcontractors and Suppliers}

Pennsylvania Type Jurisdictions. While the general contractor and his immediate subcontractors in direct-lien states have rights against the owner, subcontractors of a lesser degree and suppliers of labor and materials are sometimes barred by statute or statutory construction from imposing mechanics' liens to satisfy their claims. Whether or not a subcontractor or supplier may lien is of practical importance, since his prospective rights are a determinant of the price which he charges for his work, the manner in which he conducts it and, ultimately, his ability to stay in business. Nonetheless, the criteria for determining the class of lower subcontractors and suppliers entitled to lien not only vary widely from jurisdiction to jurisdiction but, in many states, are imprecise as well.40 Even when prescribed with any degree of clarity, limitations on the right to lien often reflect an obsolete conception of the economics and practices of the building industry. ${ }^{41}$

Despite the variety, obsolescence and imprecision of statutory criteria, most states extend the right to lien to everyone who supplies a construction project with labor and materials. Courts in these jurisdictions pay little attention to the distinctions between subcontractors and remote subcontractors or materialmen. Other commercially significant jurisdictions, however, restrict lien rights by insisting that lienors qualify as "subcontractors." 42 Where the term has an

40. For the obscurity of statutory standards, see, e.g., Shaar v. Knickerbocker Ice Co., 149 IIl. 441, 37 N.E. 54 (1894) ; People ex rel. Belson Mfg. Co. v. Wayne Elec. Motor Co., 269 Mich. 537, 257 N.W. 817 (1934). See also Wood v. Isgrigg Lumber Co., 71 Ind. App. 64, 123 N.E. 702 (1919); Hightower v. Bailey, 108 Ky. 198, 56 S.W. 147 (1900).

A clarifying bill failed of enactment in New York. Proposed by the New York Law Revision Committee in 1945, it would have specified the rights which labor and material suppliers enjoy under surety bonds running to public corporations and state agencies. N.Y. Legis. Docket No. 65L (1945). In New York, clarifying bond coverage would clarify lien rights because of N.Y. STAtE FIN. LAw $\$ 137$, which conditions bond recovery on the proving of a lien (except for the "amount due" requirement).

41. See text at notes 56-59 infra.

42. Except when a direct contractual relationship with the owner can be shown, in the following states liens have generally been denied for materials furnished to subcontractors. Delaware-Wilmington Sash \& Door Co. v. Nuttall, 29 Del. (6 Boyce) 1, 95 Atl. 902 (Super. Ct. 1915) ; Georgia-General Supply Co. v. Hunn, 126 Ga. 615, 55 S.E. 957 (1906) ; Louisiana-Ketteringham v. Eureka Homestead Soc., 140 La. 176, 72 So. 916 (1916) ; Olio-Stephens v. United R.R. Stockyards Co., 29 Ohio St. 227 (1876) ; Pennsylvania-Favo v. Merlot, $94 \mathrm{~Pa}$. Super. 90 (1928) ; Wisconsin-Dallman v. Clasen, 116 Wis. 113, 92 N.W. 565 (1902) ; District of Colmmbia-Sommerville v. Williams, 12 App. D.C. 520 (D.C. Cir. 1898) (dictum).

Definitions of "subcontractor" vary. Under some mechanics' lien statutes, a subcontractor is one who contracts with the principal contractor. E.g., Stringfellow v. Coons \& Golder, 57 Fla. 158, 49 So. 1019 (1909). Elsewhere, courts have given the term a broader meaning. Holt \& Bugbee Co. v. City of Melrose, 311 Mass. 424, 426, 41 N.E.2d 562, 564 (1942) ("one who has entered into a contract, express or implied, for the performance of an act with the person who has already contracted for its performance") ; Rogers v. Crane Co., 180 Okla. 139, 68 P.2d 520 (1937) (similar). Still others restrict the term narrowly. E.g., Hohn-Hammond Lumber Co. v. Elsom, 171 Cal. 570, 154 Pac. 12 (1915). Courts have not infrequently expressed dissatisfaction with these various statutory definitions. See, e.g., Duignan v. Montana Club, 16 Mont. 189, 40 Pac. 294 (1895). 
accepted definition, the problem of who may lien is easily resolved. ${ }^{43}$ Elsewhere, a claimant's rights may depend on whether the courts construe "subcontractor" functionally or by reference to the claimant's degree of "privity" with the owner. ${ }^{44}$ Although no subcontractor can be in privity with an owner in the strict, contractual sense, many judicial decisions use this term to indicate that the owner has knowledge of, or an ability to select and direct, subcontractors of at least the first degree.45 Since the owner generally lacks similar knowledge and control with respect to more remote subcontractors and suppliers, they are frequently denied the right to lien. ${ }^{48}$ An exception to this proposition might be made if the obvious presence of men on the job complete with equipment and signs could be deemed sufficient notice to the owner. Conversely, a person who functions as a subcontractor off the jobsite may be characterized as a supplier, and neither the services performed nor the items furnished are universally recognized indicia of whether he is in fact a "subcontractor." 47 This distinction is crucial in jurisdictions limiting lien coverage to "subcontractors."

43. For example, Pennsylvania (the most important, commercially, of the states which limit the right of lien) gives precise content to the term "subcontractor." That term is defined to include all persons who deal directly with the general contractor. Hence, "subcontractor" comprehends many persons who ordinarily would be considered materialmen, and excludes subcontractors too far removed from the general contractor. PA. STat. Ann. tit. 49, \& 4 (1930); Favo v. Merlot, supra note 42; Brown v. Cowan, $110 \mathrm{~Pa}$. 5\&8, 1 At1. 520 (1885). This definition is inconsistent with Pennsylvania's direct-lien rationale under which the general contractor is considered the owner's "agent." See notes 31, 32 supra and accompanying text. Given this rationale, a subcontractor of the first degree should be viewed as the general contractor's agent for the letting of contracts; and the owner, by the same doctrine of expectation, should be made liable for unpaid claims. For cases wrestling with this problem, see Battista v. Horton, Myers \& Raymond, 76 App. D.C. 1, 128 F.2d 29 (D.C. Cir. 1942) ; Eccleston v. Hetting, 17 Mont. \&8, 42 Pac. 105 (1895) ; Duignan v. Montana Club, 16 Mont. 189, 40 Pac. 294 (1895). See also Note, 18 Mont. L. Rev. 53, 55 (1956); Smith-Faris Co. v. Jameson Memorial Hosp. Ass'n, 313 Pa. 254, 169 At1. 233 (1933).

44. For "privity" cases, see, e.g., Spinney v. Sanford-Orlando Kennel Club, Inc., 123 Fla. 113, 166 So. 559 (1936) ; Harper Lumber \& Mfg. Co. v. Teate, 98 Fla. 1055, 125 So. 21 (1929).

45. Smith-Faris Co. v. Jameson Memorial Hosp. Ass'n, $313 \mathrm{~Pa} .254,169$ Atl. 233 (1933).

46. See, e.g., Economy Pumps v. F. W. Woolworth Co., 220 N.C. 499,17 S.E.2d 639 (1942). For general discussion, see Philnips, Mechanics' Liens 86 (1874).

47. The only consistent element among the decisions in this area is their inconsistency, even within a single state. When the services furnished consist of supplying movable items of furniture or equipment, the right of lien may be denied. E.g., Kalbach Lumber Co. v. Red Ball Chain Stores Co., 196 Iowa 854, 195 N.W. 513 (1923). A company which furnished material and labor to a subcontractor was, on the other hand, considered a subcontractor because the work furnished was not included in the original plans. Apparently, if the general contractor had been responsible for the item from the beginning, the "subcontractor" would have been viewed as a supplier of a subcontractor and not entitled to lien. Smith-Faris Co. v. Jameson Memorial Hosp. Ass'n, 313 Pa. 254, 169 Atl. 233 (1933). The status of off-site subcontractors is not free of doubt even in jurisdictions 
States which restrict the right to lien do so on the theory that suppliers and lower-degree subcontractors rely not on the credit of the improvement but on that of the contractor directly above them. ${ }^{48}$ This assumption is by no means an accurate reflection of normal trade practices. Only the law's denial of the security of the improvement to remote subcontractors forces them to look solely to the credit of higher-level contractors. In any event, those on the lower levels must undertake risks without adequate information, for they are unlikely to ascertain the credit standing of every subcontractor with whom they deal. Even if such investigation were common, information of this sort would not constitute insurance against subsequent defaults.

New York Type Jurisdictions. The New York "amount-due" rule extends the right of lien to parties further down the contractual chain than does the Pennsylvania type statute. In actuality, however, the limitations on protection resulting from the subrogative nature of the New York lienor's position decrease his security considerably below that provided by a direct or Pennsylvania lien. A lienor's rights under New York doctrine derive solely from the contractor next above him and, ultimately, depend on the general contractor's claim against the owner. ${ }^{49}$ Every lien on a given project is therefore limited to the smallest amount due (and becoming due) to any contractor mediately or immediately above the potential lienor at the time the lien is filed.50 Thus, no lienor can recover more than the sum which the owner owes the general contractor. And if any party above the lienor is paid in full, the lienor is barred from claiming against the project. Similarly, the default of any intermediary party also breaks the subrogative chain and bars the claim of a lower party who has not yet filed. ${ }^{\mathbf{1 1}}$

Since a New York lienor must prove the amount which was owing to the general contractor, he may find foreclosure difficult. ${ }^{52}$ Any payments to the

which normally allow materialmen the right of lien. Cf. Stephens v. Holmes, 64 Ill. 336 (1872) (house moving) ; Staunton v. Cole \& Fauber, 254 IIl. App. 377 (1929) (telephone services).

48. 1 Cushman, Mechanics' Liens in Pennsylvania 95-96 (1926) (collecting cases).

49. See, e.g., Widenhouse v. Russ, 234 N.C. 382, 67 S.E.2d 287 (1951) ; Ruberoid Co. v. Scott, 249 S.W.2d 256 (Tex. Civ. App. 1952).

50. The rule is applied with particular stringency in New York. E.g., Wright v. Schoharie Ry., 116 App. Div. 542 (1906), aff'd, 191 N.Y. 549, 85 N.E. 1118 (1908) ; French v. Bauer, 134 N.Y. 548, 32 N.E 71 (1892) ; Lumbard v. Syracuse, B. \& N.Y.R.R., 55 N.Y. 491 (1874). For similar decisions in other jurisdictions of the New York type, see, c.g., Koenig v. McCarthy Constr. Co., 344 Ill. App. 93, 100 N.E.2d 338 (1951); Thurber Constr. Co. v. Kemplin, 81 S.W.2d 103, 108 (Tex. Civ. App. 1935) ; cf. Hoggson Bros. v. Dickason-Goodman Lumber Co., 81 Okla. 31, 196 Pac. 686 (1921).

51. Cf. Soll v. Camardella, 277 App. Div. 1004, 100 N.Y.S.2d 187 (1950); Owens v. Ebner, 74 N.Y.S.2d 169 (Sup. Ct. 1947).

52. The lienor has and retains the burden of proof in a foreclosure proceeding. Herrmann \& Grace v. Hillman, 203 N.Y. 435, 96 N.E. 741 (1911) ; Brainard v. County of Kings, 155 N.Y. 538, 50 N.E. 263 (1898) ; Beardsley v. Cook, 143 N.Y. 143, 38 N.E. 109 (1894) ; cf. Willard Co. v. City of New York, 81 Misc. 48, 142 N.Y. Supp. 9 (Sup. Ct. 1913). 
general contractor subsequent to the filing of a lien are, of course, conclusive evidence of the minimum amount due. ${ }^{53}$ But if payments have been suspended and the owner does not acknowledge a specific indebtedness, the lienor is frequently unable to prove the amount due. ${ }^{54}$ Even progress reports, when available, are not reliable indications of the value of the labor and material invested in a project. ${ }^{55}$ On the one hand, overreporting is a notorious and widespread practice; on the other, underreporting may occur when a job has been seriously underbid and the general contractor is forced to limit his requests for payment to what appears reasonable in light of the contract price. If the progress-payment system is not used and the contract is entire, a subcontractor cannot prove any amount due except by demonstrating that the general contractor could elicit payment through a suit in quantum meruit. ${ }^{56} \mathrm{~A}$ showing that the general contractor has substantially performed in good faith under the contract might then sustain at least part of the subcontractor's lien. ${ }^{57}$ Ironically, such proof may be impossible if the subcontractor, in following the contractor's instructions, furnished work which was at variance with the owner's plans and specifications. ${ }^{58}$ Analogously, if the general contractor has simply abandoned the work and the contract was entire, a would-be lienor could recover nothing. ${ }^{\text {to }}$

Liens of the New York type are also diminished whenever an owner avails himself of his right to apply the unpaid balance owed the general contractor

53. See, e.g., F. Bowden Co. v. Baier, 99 N.J.L. 361, 123 Atl. 737 (Sup. Ct. 1924) (payment by owner after the filing of a stop-notice).

54. See American Radiator Co. v. City of New York, 223 N.Y. 193, 119 N.E. 389 (1918); Herrmann \& Grace v. Hillman, 203 N.Y. 435, 96 N.E. 741 (1911); Foshay v. Robinson, 137 N.Y. 134, 32 N.E. 104 (1893).

55. See, e.g., CResweil, Building ANd Engrneering Contracts 176 (1957).

56. Ruddy v. McDonald, 244 I1l. 494, 499, 91 N.E. 651, 653 (1910) ; Bartson v. Wiekert, 193 I11. App. 467 (1915). If specifically required by the contract, an architect's certificate will also be considered a prerequisite to recovery. See, c.g., Gilmore v. Courtney, 158 Ill. 432, 41 N.E. 102 (1895); Michaelis v. Wolf, 136 I1l. 68, 26 N.E. 384 (1891).

Proof of the amount due by lienors is facilitated in the five jurisdictions which require the owner, on demand, to furnish every claimant a copy of the general contract and a statement of the amount due or to become due. These jurisdictions are California, District of Columbia, Michigan, New York and Ohio.

57. Heckmann v. Pinkney, 81 N.Y. 211 (1880). An intentional and wilful departure from the requirements of the contract or specifications will bar recovery. E.g., Cramer v. Esswein, 220 App. Div. 10, 220 N.Y. Supp. 634 (1927).

58. For cases denying recovery, see, e.g., Terrell v. McHenry, 121 Ky. 452, 89 S.W. 306 (1905) (leaking roof); Fitzgerald v. Schaerfer, 216 S.W.2d 939 (Mo. Ct. App. 1949) (defective materials) ; Mink v. Heep, 223 App. Div. 220, 227 N.Y. Supp. 698 (1928) (wrong structure in wrong place). For cases allowing recovery, see, e.g., Coonse \& Caylor Ice Co. v. Howe Stove Co., 70 Ind. App. 226, 121 N.E. 293 (1918) (defective stoker, later removed); Bowen v. Phinney, 162 Mass. 593, 39 N.E. 283 (1895) (faulty paint job; decision under statute no longer in force); W. H. Pipkorn Co. v. Tratnik, 161 Wis. 91, 152 N.W. 141 (1915) (walls condemned).

59. Lemieux v. English, 19 Misc. 545, 43 N.Y. Supp. 1066 (Sup. Ct. 1897) ; if. Herrmann \& Grace v. Hillman, 203 N.Y. 435, 96 N.E. 741 (1911), affirming 139 App. Div. 902, 123 N.Y. Supp. 1120 (1910). 
toward completing work under the contract. ${ }^{60}$ Thus, the owner may finance the actual cost of completion out of funds which were or eventually would have become due the general contractor in the absence of default. ${ }^{61}$ Even if a liquidated sum is specifically due on the contract at the time that a lien is filed (or such a sum becomes due thereafter), an exercise of the owner's rights will decrease the amount available to lienors to the balance owed on the contract less the cost of completion. ${ }^{62}$ The owner's rights under the law may be further enhanced by provisions found in the vast majority of contracts. These permit the withholding of an amount corresponding to the general contractor's overdue payments to his suppliers and subcontractors, and also allow the general contractor's failure to pay his subcontractors or suppliers to be treated as a material breach. ${ }^{63}$

\section{Lienability}

Besides establishing that he is among the class of persons comprehended by the statute, a potential lienor must demonstrate that the goods or services actually rendered in the case at issue entitle him to a lien. Many items do not give rise to liens because they are considered unnecessary to the construction process. ${ }^{64}$ For example, some courts, evidently ignoring the technological developments of the past century, will not enforce liens for fuel used to run building machinery 65 or to provide heat during cold-weather construction. ${ }^{66}$ Apparently, legal changes

60. The owner also may recover the cost of replacing defective work. See, e.g., Rubin v. Coles, 142 Misc. 139, 253 N.Y. Supp. 808 (N.Y. City Ct. 1931).

61. Van Clief v. Van Vechten, 130 N.Y. 571, 577, 29 N.E. 1017 (1892); De Lorenzo v. Von Raitz, 44 App. Div. 329, 60 N.Y. Supp. 736 (1899) ; Clark v. Fleischmann Vehicle Co., 187 N.Y. Supp. 807 (Sup. Ct. 1921) ; J. W. Van Cott \& Son v. Gallon, 163 Misc. 914, 922, 298 N.Y. Supp. 67 (Delaware County Ct. 1937) (dictum).

Any retained percentages from previous payments may be freely used by the owner in the course of completing the project after a default by the general contractor. If these percentages are exhausted, the lienor may not include them in computing the "amount due," for, under the contract, they are not due. See note 26 supra and accompanying text.

62. Jensen, Mechanics' Liens $\$ 307$ (3d ed. 1929) (collecting cases).

63. For such a provision in a widely used contract form, see Parker \& AdAMis, The A.I.A. Standard Contract Foras and the Law 91, 92 (arts. 22, 26(c)) (1954).

An owner who withholds amounts corresponding to the general contractor's overdue debts is likely to pay them directly to the general contractor's creditor subcontractors and suppliers. But if an owner elects to treat the general contractor's arrearage as a material breach, the subcontractors and suppliers will probably lose all but their legal and equitable remedies with respect to the project.

64. See generally Profits Not Lienable, 28 Heating, Piprng \& Air-conditioning 141 (1956); Law and Profits, 25 Heating, Piprng \& Air-condrtioning 110 (1953). See also cases cited, notes 65-68 infra.

65. Cincinnati R. \& M.R.R. v. Shera, 36 Ind. App. 315, 73 N.E. 293 (1905); Shultz v. C. H. Quereau Co., 210 N.Y. 257, 104 N.E. 621 (1914) ; Richstein v. Roesch, 71 S.D. 451, 25 N.W.2d 558 (1946) ; Carnegie Fuel Co. v. Interstate Transfer Ry., 165 Wis. 46, 160 N.W. 1046 (1917).

66. Schroeter Bros. Hardware Co. v. Croatian "Sokol” Gymnastic Ass'n, 332 Mo. 440, 58 S.W.2d 995 (1933). Contra, Oliver L. Taetz, Inc. v. Groff, 363 Mo. 825, 253 S.W.2d S24 (1953) ; Walker v. Collins Constr. Co., 121 Neb. 157, 236 N.W. 334 (1931). 
have likewise gone unobserved. Contractors may not lien for premiums paid on workmen's compensation or public liability insurance, nor for licensing or other taxes essential to the conduct of building operations. ${ }^{67}$ Thus, the lienor may fail to recover many costs integral to his performance on a given project. And, prior to undertaking a job, he will be uncertain about the lienability of numerous items whose status remains unlitigated. At present, liens may represent only the value of goods or services made "a part of the improvement," but confusion reigns supreme under the various imprecise restatements and conflicting applications of this vague standard. ${ }^{68}$

\section{Filing and Attachment}

Depending on the jurisdiction, a properly filed lien will effectively attach as of either the day the original contract was made, the time of breaking ground, the date of filing, or the moment when the lienor commenced or completed work. ${ }^{69}$ The right to lien is lost if filing does not occur within the time specified by law. ${ }^{70} \mathrm{~A}$ failure to comply exactly with the statutory requirements prevents an applicant from even attaining the status of a lienor, because the lien acts are strictly construed as derogations of the owner's common-law rights. ${ }^{71}$ In a number of jurisdictions, a lienor must not only file properly but also notify the owner of the claim; lien rights against the owner will then depend on and

67. E.g., Mann v. Schnarr, 228 Ind. 654, 95 N.E.2d 138 (1950); Hoier v. Kaplan, 313 III. 448,145 N.E. 243 (1924). But see Bangor Roofing \& Sheet Metal Co. v. Robbins Plumbing Co., 151 Me. 145, 116 A.2d 664 (1955).

68. For a case reflecting this confusion, see Barnes v. Montana Lumber \& Hardware Co., 67 Mont. 481, 216 Pac. 335 (1923).

In many jurisdictions, recovery for items under a surety bond is made dependent on the initial liability of the item. See Wilson-Stamey Grocery Co. v. Ross, 194 N.C. 109, 138 S.E. 537 (1927); Park, What Constitutes Labor and Material in a Labor and Matcrial Bond, 16 Ins. Counser J. 14 (1949). Other states take the opposite view-that the lien law does not control in construing the bond. E.g., American Sur. Co. v. James A. Dick Co., 23 F.2d 464 (8th Cir. 1927) (applying New Mexico law); Fuller v. Brooks, 117 Okla. 252, 246 Pac. 369 (1926) ; Franzen v. Southern Sur. Co., 35 Wyo. 15, 246 Pac. 30 (1926).

69. The lien attaches as of the time work commences on the building or improvement in: Alabama, Arkansas, California, Colorado, District of Columbia, Florida, Kansas, Maryland, Michigan, Minnesota, Montana, New Mexico, Ohio, Oklahoma, South Dakota, Tennessee and Wyoming. The date notice of lien is filed controls in: Arizona, Mississippi, Missouri, North Dakota, New Jersey, New York, Rhode Island, South Carolina, Texas, Vermont, Washington and Wisconsin. The lien attaches as of the actual date on which labor or supplies were furnished in: Connecticut, Delaware, Georgia, Indiana, Iowa, Kentucky, Nebraska, Nevada, New Hampshire, Utah and West Virginia. The remaining jurisdictions have less precise rules.

70. E.g., ME. Rev. Stat. Ann. ch. 178, § 36 (1954); Marshall v. Mathieu, 143 Me. 167, 57 A.2d 400 (1948); N.Y. LiEN LAW \& 10; Stevens v. Ogden, 130 N.Y. 182, 29 N.E. 229 (1891).

71. E.g., Kelley v. Springer, 235 Ill. 493, 85 N.E. 593 (1908) ; Heidenbluth v. Rudolph, 152 I1l. 316, 38 N.E. 930 (1894); cf. Hoffman Lumber Co. v. Mitchell, 170 Pa. Super. 326, 85 A.2d 664 (1952). 
date from such notification. ${ }^{72}$ Filing, however, need not always await the existence of an unpaid, matured claim, since some states allow filing immediately upon the completion of work or even before the delivery of materials. ${ }^{73}$

\section{Priorities}

Under the majority of statutes, all lienors of the same class who file within the statutory period receive equal treatment without regard to the order in which their claims arose or their liens were filed. Thus, on foreclosure, all subcontractors and suppliers, who are treated as a class, share pro rata that class's portion of the proceeds. ${ }^{74}$ Priorities exist among classes, however, so that ordinarily the liens of subcontractors and suppliers take precedence over those of the general contractor, ${ }^{75}$ and the liens of laborers for daily wages are satisfied first. ${ }^{76}$

A valid subcontractor's lien on the property may be subordinated not only to laborers' liens but also to claims by creditors of the general contractor. In some jurisdictions following the New York rule, when the general contractor assigns his rights under the contract to secure loans from a third party, precedence as between a subcontractor and the assignee will depend on the order in which the subcontractor's lien and the assignment are filed.77 Since, under the New York rule, the owner cannot be compelled to pay more than the amount due the contractor, an assignee's priority diminishes pro tanto the lien claims allowable against the owner's property. ${ }^{78}$ Moreover, under the first-in-time,

72. For statutes of this sort, see note 25 supra.

73. See, e.g., Palmer Lumber Co. v. Stern, 140 App. Div. 680, 125 N.Y. Supp. 594 (1910) ; Saginaw Lumber Co. v. Wilkinson, 266 Mich. 661, 254 N.W. 240 (1934) ; Benning v. Farmers' Bank, 190 S.W. 983 (Mo. Ct. App. 1916).

74. E.g., Ariz. Code ANn. § 62-215 (1939); Del. Code Ans. tit. 25, § 2720 (1953); Fla. Stat. Ann. \& 84.20 (1943).

75. E.g., N.Y. LIEN LAW \$ 56; FLA. Stat. ANN. § 84.06 (1943).

76. E.g., GA. Code Ann. $\S 67-2002(3)$ (1938) ; Mich. Stat. Ann. $\$ 26.296$ (1953); N.J. Stat. Ann. \$2A :44-86 (1952); N.Y. Lien LAw \$ 13(1), American Radiator Co. v. City of New York, 223 N.Y. 193, 198, 119 N.E. 391, 393 (1918); Orio Rev. Code Ann. $\S 1311.13$ (Page 1953); Okla. Stat. Ann. tit. 42, $\S \S 92-96,171$ (1954), Central Fin. Corp. v. Brown, 175 Okla. 528, 54 P.2d 196 (1936).

77. Riverside Contracting Co. v. City of New York, 218 N.Y. 596, 113 N.E. 564 (1916) ; S.C. CODE $\$ 45-252$ (1952) ; Vr. STAT. \$ 2754(IV) (1947); Weissman v. Volino, 84 Conn. 326, 80 Atl. 81 (1911); Gray v. McClellan, 214 Mass. 92, 100 N.E. 1093 (1913); Landers-Morrison-Christenson Co. v. Ambassador Holding Co., 171 Minn. 445, 214 N.W. 503 (1927) ; Haney-White Co. v. Stafford, 96 N.J.L. 283, 114 Atl. 746 (Ct. Err. \& App. 1921) ; Kingsport Brick Corp. v. Bostwick, 145 Tenn. 19, 235 S.W. 70 (1921) ; Guaranty Title \& Trust Co. v. Thompson, 93 Fla. 983, 113 So. 117 (1927) (dictum).

78. Bates v. Salt Springs Nat'l Bank, 157 N.Y. 322, 51 N.E. 1033 (1898); Lauer v. Dunn, 115 N.Y. 405, 22 N.E. 270 (1889); New York County Nat'1 Bank v. Wood, 169 App. Div. 817, 153 N.Y. Supp. 860 (1915), aff'd, 222 N.Y. 662, 119 N.E. 1062 (1918); Contractors' Supply Co. v. City of New York, 153 App. Div. 60, 138 N.Y. Supp. 242 (1912) ; Tapai v. Demartini, 77 Cal. 383, 19 Pac. 641 (1888) ; cf. Rubinstein v. Jamaica Nat. Bank, 40 N.Y.S.2d 23 (Sup. Ct. 1943). But see John Murtland, Inc. v. Empire Trust Co., 39 F.2d 341 (3d Cir. 1930). In many jurisdictions, if the monies advanced under 
first-in-right theory, the prior filing of an assignment will defeat a lien even if the funds advanced by the assignee were wasted or used on a different project. $^{79}$ Of course, the lender-assignee may require that the monies advanced be held by the contractor as a trust fund for the payment of construction costs. This requirement will not protect the lienor, however, once the fund has been misappropriated. In New York, misuse of the fund is a crime, but prosecutions are rare. ${ }^{80}$ The lienor's civil action against the contractor for wasting the trust is also ineffective because of the contractor's normal financial condition when liens are being foreclosed..$^{81}$

In addition, a subcontractor's lien rights may be subordinated to the rights of creditors of the owner. His priority is usually lower than that of purchasemoney or general-construction mortgagees, unless his lien attached before the filing of the mortgage. ${ }^{82}$ Moreover, in a few jurisdictions the mortgagee has first priority regardless of when the mechanic's lien attaches, so long as the mortgage is recorded during construction and contains provisions which bar any diversion of the mortgage funds from the project. ${ }^{83}$ In one of these states, the mortgagee does not receive the same incentive to lend, because he may lose his priority if the funds advanced are actually diverted from the improvement. ${ }^{84}$ Departing from the usual all-or-nothing approach to priori-

a mortgage financing an improvement are mingled with the mortgagor's general funds, the mortgage will take precedence over the mechanic's lien only to the extent of the sum actually used in erection of the improvement. See W. P. Fuller \& Co. v. McClure, 48 Cal. App. 185, 191 Pac. 1027 (Dist. Ct. App. 1920) ; Riverside Apartment Corp. v. Capitol Constr. Co., 107 N.J. Eq. 405, 152 Atl. 763 (Ch. 1930), aff'd, 110 N.J. Eq. 67, 158 At1. 740 (Ct. Err. \& App. 1932) ; Micele v. Falduti, 101 N.J. Eq. 103, 137 Atl. 92 (Ch. 1927) ; Haney-White Co. v. Stafford, supra note 77; Friedman v. Board of Educ., 256 App. Div. 318, 10 N.Y.S.2d 85 (1939) (public contract); Vacuum Oil Co. v. Liberty Ref. Co., 265 S.W. 749 (Tex. Civ. App. 1924).

79. See note 69 supra.

80. For the criminal provision, see N.Y. LIEN LAw \$§ 13(3), (7), 36(a) (Supp. 1958); cf. Tenn. Code Ann. \$ 64-1142 (1955).

81. The civil action is authorized by N.Y. LIEN LAw $\S 36$.

82. Franklin Soc'y v. Thornton, 85 N.J. Eq. 37, 95 Atl. 374 (Ch. 1915). A purchasemoney mortgage given by one who purchases the property after construction has begun takes precedence over mechanics' liens despite the fact that the building may be nearly complete at the time the mortgage is executed. Gibbs v. Grant, 29 N.J. Eq. 419 (Ch. 1878).

83. E.g., N.Y. Lien Law § 13(2), (3) ; Telsey v. Calvin-Morris Corp., 260 N.Y. 456, 184 N.E. 53 (1933), affirming 235 App. Div. 722,255 N.Y. Supp. 964 (1932). Sections 13 (2) and (3) of the New York act do not apply to purchase-money mortgages. Shilowitz v. Wadler, 237 App. Div. 330, 261 N.Y. Supp. 35 (1932) ; cf. N.J. Stat. Ans. \$\$ 2A :44-\$7, 89 (1951) (imposing a duty on the mortgagee to see that advances made are applied to the project); OHio Rev. CoDe ANn. § 1311.14 (Page 1953).

84. Riverside Apartment Corp. v. Capitol Constr. Co., 107 N.J. Eq. 405,152 Atl. 763 (Ch. 1930), aff'd, 110 N.J. Eq. 67, 158 Atl. 740 (Ct. Err. \& App. 1932). The requirements placed on the lender by the New Jersey approach seem unduly burdensome; he must either continually police the general contractor or run the risk of losing his security. See Holl, Construction Loans, 70 N.J.L.J. 289 (1947).

Under the New Jersey system, a construction (non-purchase-money) mortgage takes: first priority only if, at the time of recording or registering, the building on the land has 
ties, certain western states set aside only the value of the land to meet the claims of mortgagees, and reserve the value of the improvement to satisfy contractors' liens pro rata. ${ }^{85}$

Whenever the time of filing governs the lienor's rights as against other classes of creditors, the unpaid subcontractor or supplier may be well advised to file early. By so doing, however, he can precipitate the filing of other liens which, in turn, can cause the general contractor's default. For instance, the owner may treat the general contractor's now-obvious failure to pay as a default under a "no unpaid claims" clause in the contract, or as a material breach in the absence of such a clause. ${ }^{86}$ Or else, subcontractors may slow down their work progress until payment is forthcoming, or may abandon the job to sell their services to a more reliable buyer. Likewise, laborers may leave of their own accord or be removed by their unions. Furthermore, credit sources on which the general contractor depends will probably be cut off, and his creditors on other jobs may demand immediate payments which he is unable to make.

Many lien statutes partially solve the problem of precipitous filing by allowing a lien to relate back to a time earlier than the date of filing. ${ }^{87}$ The unpaid subcontractor can thus postpone filing without being prejudiced by intervening claims. In addition, since most statutes treat all valid mechanics' liens equally, regardless of the time of filing, the subcontractor generally does not forfeit any priority by waiting. As a consequence, accumulated liens leading to a general contractor's default may be avoided. On the other hand, the longer an inevitable default is deferred, the larger the liens that will eventually be filed can become and the smaller each prospective lienor's share on foreclosure is likely to be. ${ }^{88}$ The unpaid subcontractor must therefore weigh the chance that his postponement of filing will enable the contractor to avoid default against the possibility that accumulating claims will diminish his eventual recovery. And the potential lender must remember that the relation-back

been substantially or fully completed and no mechanics' notices of intention to lien have been filed; or if no buildings, excavation, footing or foundation is on the land; or if no labor or materials have been furnished for building within four months of the time of recording or registering. N.J. Stat. Ans. $\$ 2 A$ :44-88 (1950) ; cf. Companaro v. Gondolfo, 60 F.2d 451 (3d Cir. 1932). A mortgage which is part purchase-money and part to secure a loan for actual construction generally takes precedence over mechanics' liens in New Jersey. Franklin Soc'y v. Thornton, 85 N.J. Eq. 37, 95 Atl. 374 (Ch. 1915).

85. See, e.g., MoNt. Rev. Codes ANN. § 45-501 (1947). This approach has been followed in Illinois. Ilz. REv. Stat. ch. 82, § 16 (1957) ; Bradley v. Simpson, 93 Ill. 93 (1879); cf. Newark Lime \& Cement Co. v. Morrison, 13 N.J. Eq. 133 (Ch. 1860) ; Grand Opera House Co. v. Maguire, 14 Mont. 558, 37 Pac. 607 (1894).

Under the Illinois approach, the value of the lien is the market value added to the property by the improvement, not the value of the labor and materials furnished. Valuation is thus unnecessarily complex. See Crosky v. North W. Mfg. Co., 48 Ill. 481 (1868).

86. For these clauses, see note 63 supra and accompanying text.

87. See note 69 supra.

88. These disadvantages may be partially affset in jurisdictions of the New York type, since the later a default the larger the "amount due" may be. 
statutes can operate to cause liens arising on claims not yet in existence to assume priority and diminish, if not altogether extinguish, his security. ${ }^{80}$

A few jurisdictions apply the first-in-time, first-in-right theory among all mechanics' lienors. ${ }^{90}$ Since the time of filing determines priority in these states, the incentive to file early is strong, and the first filing may trigger a deluge of liens and, ultimately, a default.

\section{Diversion of Funds}

A lienor whose claim has arisen on one project may not assert his lien against either the amount due or the property on any other project which the general contractor has undertaken, even when the owner is also the same. ${ }^{01}$ Similarly immune are funds due the general contractor for other work on the same construction project, if the work was performed under an agreement separate from the general contract. ${ }^{92}$ These restrictions-confining lien rights to the project on and contract under which the claimant worked-do not comport with common business practice. A contractor will frequently finance one job with payments from other projects for which funds are readily available. This robbing of Peter to pay Paul occurs even in states where statutory provisions denominate revenues from a given project as a trust fund for the payment of that project's creditors, and make any diversion of the fund a felony. Enforcing such a trust is impractical, for the process of tracing diverted funds is fraught with difficulty unless the contractor has been both honest and accurate in his bookkeeping. Not suprisingly, under-financed, speculating contractors whose bookkeeping is purposely unclear are those who most often engage in interproject financial maneuvering. Thus, the mechanics' lien statutes fail to protect the subcontractor and supplier against yet another important cause of default and ultimate loss. On the other hand, were the innocent transferees of wrongly diverted funds forced to disgorge, and were liens freely enforceable on all of a general contractor's projects, the determination of priorities and the interaction of defaults might engender a confusion so great that the remedy would turn out to be worse than the current wrongdoing.

89. Federal Land Bank v. Green, 108 Mont. 56, 90 P.2d 489 (1939) ; Federal Trust Co. v. Guigues, 76 N.J. Eq. 495, 498, 74 Atl. 652 (Ch. 1909) ; Erdman v. Moore, 58 N.J.L. 445, 33 Atl. 958 (Sup. Ct. 1896). See also Davis v. Bilsland, 85 U.S. 659 (1873) (construing Montana law).

90. E.g., Iowa CoDE ANN. \& 572.17 (1949).

91. E.g., C. T. Willard Co. v. City of New York, 81 Misc. 48, 142 N.Y. Supp. 9 (Sup. Ct. 1913); Quinlan v. Russel, 94 N.Y. 349 (1884). Consequently, the mechanics' lienor is at a comparative disadvantage. Certain classes of creditors-in particular the federal government as lienholder for unpaid taxes-may reach other funds in order to satisfy debts arising from the principal job; conversely, they may also reach the fund due the contractor on the principal job to satisfy liens on other projects. See Kennedy, Thc Relative Priority of the Federal Government: The Pernicious Career of the Inchoate and General Lien, 63 YaLE L.J. 905 (1954); cf. Note, 66 Y ALE L.J. 797 (1957).

92. Streever Lumber Co. v. Mitchell, 183 App. Div. 129, 170 N.Y. Supp. 272 (1918). 


\section{Ozener Consent and Disclaimer}

A subcontractor or supplier who has safely negotiated the obstacles discussed thus far may still lose part or all of his lien. Property is lienable only if the general contractor was engaged on the authority of a person who is the property's "owner" within the meaning of the statute. ${ }^{93}$ Frequently, liens are invalidated because they are on improvements whose construction was authorized by a tenant or other holder of less than a fee simple interest in the property. The average subcontractor or supplier rarely examines the pertinent title records, and may not even be aware of the significance of the property interest in the apparent owner. The farther down the contract chain a subcontractor or supplier is, the more protection he will need against his own ignorance and lack of diligence.

Before a mechanic's lien may attach to land or the improvement at issue, the fee owner of the property must consent to the construction of the improvement. What constitutes consent has been resolved in a bewildering variety of ways. $^{94}$ In New York, the owner's "mere knowledge" that work is going forward coupled with his acquiesence has been held insufficient evidence of his consent. $^{05}$ Some New York decisions express the view that consent can arise in a specific contract but not in an owner's written agreement to the effect that his lessee may make and pay for repairs or minor alterations and additions. ${ }^{96}$ Other New York cases hold, however, that when the conduct and attitude of the owner indicate a willingness to benefit by the improvement, his consent will be implied. ${ }^{97}$ Inconsistencies of this sort are by no means limited to New York. $^{88}$

93. E.g., N.Y. LIEN LAW \& 3 (Supp. 1958); N.J. Stat. ANn. § 2A:44-68 (1951); Det. Cone Ann. tit. 25, § 2722 (1953).

94. E.g., Valenti v. New York Theatre Co., 99 Misc. 517, 166 N.Y. Supp. 76, 77 (Sup. Ct. 1917) (knowledge and acquiescence not sufficient to constitute consent); Avery v. Smith, 96 Conn. 223, 113 Atl. 313 (1921) (agreement to be liable is required); Clark v. North, 131 Wis. 599, 111 N.W. 681 (1907) (a "meeting of the minds" and a common understanding as to who should pay required).

95. Petrillo v. Pelham Bay Park Land Co., 119 Misc. 146, 196 N.Y. Supp. 124 (Sup. Ct. 1922) ; Garber v. Spivak, 65 Misc. 37, 119 N.Y. Supp. 269 (Sup. Ct. 1909) ; cf. Crowley Bros. v. Ward, 322 Ill. App. 687, 54 N.E.2d 753 (1944).

96. C. Wilson's Plumbing Shop on Wheels, Inc. v. Trustees of Dartmouth College, 168 Misc. 376, 6 N.Y.S.2d 671 (Sup. Ct. 1938) ; Valenti v. New York Theatre Co., 99 Misc. 517, 166 N.Y. Supp. 76 (Sup. Ct. 1917).

97. Majestic Tile Co. v. Nicholls, 161 Misc. 231, 291 N.Y. Supp. 551 (Nassau County Ct. 1936) ; Marsh v. Lemon Thomson Realty Corp., 174 App. Div. 218, 160 N.Y. Supp. 138 (1916).

98. The Pennsylvania statute requires written evidence that the improvement is intended for the owner's immediate use and benefit. PA. STAT. ANN. tit. 49, $\S 24$ (1930). But the statute also imposes liability on the owner whenever the tenant "acts as if he were the owner" and makes a contract for which a claim could be filed, and the owner, knowing this, does not object. Pa. Stat. Ann. tit. 49, $\$ 28$ (1930). The Supreme Court of Pennsylvania construed $\$ \S 24$ and 28 to mean that, while the owner may consent to his tenant's 
Attempted statutory reforms have not proved successful. A Minnesota act -copied in other jurisdictions-establishes a conclusive presumption that the real owner of the land has authorized any improvement of which he was aware at any time during its construction. ${ }^{99}$ But the act intentionally provides a loophole which, practically speaking, enables an owner to negate the presumption. If he has not engaged the general contractor, has not expressly consented to the project, and gives adequate and timely notice of his "nonresponsibility" for the work, no mechanic's lien may attach to his interest. ${ }^{100}$ Thus, once notice is effected, a claimant under the statute, like a claimant without the statute, must prove consent in fact. In some jurisdictions the owner may give notice by putting a disclaimer on public file. ${ }^{101}$ This procedure manifestly will not influence those many subcontractors or suppliers who are so unsophisticated as to fail to search the public records for evidence of every apparent owner's true status and every feeholder's disclaimer.

In Pennsylvania and a number of other states, the contractor and the lessee and lessor of the property can destroy all right of lien through publicly filing the contract. The contractor can incorporate a waiver of his and his subordinates' lien rights in the contract, and the real and apparent owners can both insert disclaimers of responsibility, even though one of them engaged the general contractor. ${ }^{102}$ Furthermore, an unfiled disclaimer is effective against any

improvements without assuming liability for the work done, liability should be imposed if the owner was put on notice that the contractor believed that the tenant had authority to make an agreement which would bind the property, and the owner failed to object. Fluke v. Lang, 283 Pa. 54, 128 Atl. 663 (1925). See also N.J. Star. Ann. \$ 2A:44-68 (1951). Owner attempts to avoid liability by using improvement leases which permit but do not require the lessee to build ordinarily fail, because courts usually find that improvements have actually been erected at the behest of the owner. See, e.g., Hall v. Parker, $94 \mathrm{~Pa}$. 109 (1880); cf. Watson Land \& Improvement Co. v. Salyers, 247 Pa. 454, 93 Atl. 495 (1915) ; Annot., 79 A.L.R. 962, 965 (1932).

99. Minn. Stat. ANN. $\$ 514.06$ (1947). The constitutionality of this provision has not yet been tested. The Minnesota act has been copied in CAL. CIv. Proc. Cone $\$ 1183.1$ (1955) ; Nev. Rev. Stat. § 108.140 (1956); N.M. Stat. AnN. § 61-2-10 (1953); ORE. Rev. Stat. $\$ \S 87.030, .265$ (1953) ; S.D. CoDE $\$ 39.0706$ (1939).

100. Ott Hardware Co. v. Yost, 69 Cal. App. 2d 593, 159 P.2d 663 (Dist. Ct. App. 1954) ; Western Lumber \& Mill Co. v. Merchants' Amusement Co., 13 Cal. App. 4, 108 Pac. 891 (Dist. Ct. App. 1910) ; Skidmore v. Eby, 57 N.M. 669, 262 P.2d 370 (1953) ; Petrakis v. Krasnow, 54 N.M. 39, 213 P.2d 220 (1949) ; Nicolai-Neppach Co. v. Poore, 120 Ore. 163, 251 Pac. 268 (1926) ; Oregon Lumber \& Fuel Co. v. Nolan, 75 Ore. 69, 143 Pac. 935 (1914), aff'd on rehearing, 75 Ore. 81, 146 Pac. 474 (1915).

101. Nev. Rev. Stat. \& 108.140 (1956).

Another means of giving notice is to post at the project site conspicuous signs on which appear disclaimers of responsibility. E.g., ORE. Rev. STAT. $\$ 87.030$ (1953) ; Marshall v. Cardinell, 46 Ore. 410,80 Pac. 652 (1905) ; N.M. Stat. Ann. \$ 61-2-10 (1953). Such posting will obviously afford little notice to suppliers or remote subcontractors who do not actually appear on the jobsite.

102. Contractual provisions against mechanics' liens have been held valid in the following states: Connecticut-Weinberg v. Valente, 79 Conn. 247, 64 Atl. 337 (1906) ; Illinois- 
subcontractor who had actual notice of it prior to furnishing labor or materials. ${ }^{103}$ An intermediate group of jurisdictions, on the other hand, hold that the subcontractor retains his right to lien unless he has clearly assented to be bound by a waiver or disclaimer. ${ }^{104}$ And states following the New York rule refuse to recognize any form of exculpatory clause favoring the owner, irrespective of the lienor's prior consent; ${ }^{105}$ an express contract not to lien is enforceable, however. ${ }^{106}$

'The reasons behind the states' divergent views on owners' disclaimers is relatively clear. In Pennsylvania, the owner's direct liability to all lienors, once established, is virtually unlimited. ${ }^{107}$ But in New York, the owner is never liable beyond the amount due the general contractor, and the added protection of a disclaimer would therefore border on the gratuitous. ${ }^{108}$

Although the Pennsylvania owner needs some method by which to limit his liability, to allow him to do so completely at the expense of every prospective lienor seems unfair. No perfect answer to the disclaimer question is foreseeable, however, because the lien system necessarily contemplates that some relatively innocent party will eventually sustain whatever loss occurs. Possibly, the best solution in Pennsylvania type jurisdictions would be to allow disclaimers for all liens above the contract price-a readily ascertained and not unreasonable limit. ${ }^{109}$

Harman H. Hettler Lumber Co. v. Hodge, 227 IIl. App. 383 (1923) ; Indiana-Fuhrman v. Frech, 60 Ind. App. 349, 109 N.E. 781 (1915) ; Iowa-Van Dyck Heating \& Plumbing Co. v. Central Iowa Bldg. Co., 200 Iowa 1003, 205 N.W. 650 (1925); Maryland-Pinning v. Skipper, 71 Md. 347, 18 Atl. 659 (1889); Minnesota-Cushing v. Hurley, 112 Minn. 83, 127 N.W. 441 (1910) ; Missouri-Isenman v. Fugate, 36 Mo. App. 166 (1889) ; Nebraska -Frost v. Falgetter, 52 Neb. 692, 73 N.W. 12 (1897); Oregon-Hughes v. Lansing, 34 Ore. 118, 55 Pac. 95 (1898); Penusylvania-Long v. Caffrey, 93 Pa. 526 (1880); Wisconsin- Brzezinski v. Neeves, 93 Wis. 567, 67 N.W. 1125 (1896); compare Davis v. La Crosse Hosp. Ass'n, 121 Wis. 579, 99 N.W. 351 (1904).

Similar provisions have been held valid as to subcontractors but not as to the general contractor. Idaho-Smith v. Faris-Kesl Constr. Co., 27 Idaho 407, 150 Pac. 25 (1915); Illinois-Concord Apartment House Co. v. O'Brien, 128 Ill. App. 437, aff'd, 228 IIl. 476, 81 N.E. 1076 (1906); Massachusetts-Porier v. Desmond, 177 Mass. 201, 58 N.E. 684 (1900).

103. E.g., Bennar v. Central Mausoleum Co., 304 Pa. 569, 156 Atl. 239 (1931). See McCrady-Rodgers Co. v. Nenoff, 155 Pa. Super. 555, 39 A.2d 260 (1944). The "no lien" provision need not be in a separate contract, but may be contained in the principal contract. Deets v. Freed, 165 Pa. Super. 495, 69 A.2d 159 (1949).

104. E.g., Morin Lumber Co. v. Person, 110 Mont. 114, 99 P.2d 206 (1940). The fact that the subcontractor has knowledge of such an agreement does not bind him unless he clearly assented to it. Cf. Higby v. Hooper, 124 Mont. 331, 221 P.2d 1043 (1950).

105. E.g., North Am. Iron Works, Inc. v. G. De Kimpe, Inc., 232 App. Div. 579, 251 N.Y. Supp. 144 (1931); Carroll McCreary Co. v. People, 267 N.Y. 37, 195 N.E. 675 (1935).

106. N.Y. LIEN LAW $\$ 34$.

107. See text at note 30 supra.

108. See text at note 22 supra.

109. One further aspect of the disclaimer problem involves owners of property who hold it as trustees under instruments which do not authorize the making of improvements. 


\section{LICENSING}

Much of the subcontractor and supplier's need for protection stems from the presence of professionally unfit and thinly capitalized contractors in the construction industry. Seeking to reduce the incidence of default caused by incompetence or insolvency, most states have enacted legislation which requires contractors to be licensed or otherwise to meet minimum standards. ${ }^{110}$ These laws are of three main types. The first establishes prerequisites to the awarding of public-works contracts (both state and municipal) by limiting the bidding on such contracts to those who submit satisfactory information concerning their financial status, plant and equipment, and prior experience. ${ }^{111}$ Second are the statutes which compel the submission of the same information, but apply to private as well as public projects. ${ }^{112}$ The third and most proliferous kind of legislation provides for the licensing of various individual trades within the construction industry and, typically, for supplemental examinations, bonds and other elaborate preliminaries. ${ }^{113}$

Such a trustee cannot bind the trust by allowing unpaid claims to accasion the filing of mechanics' liens. Allison \& Ver Valen Co. v. McNee, 170 Misc. 144, 9 N.Y.S.2d 708 (Sup. Ct. 1939). A lien filed under these circumstances would probably be held invalid on the theory that the trustee was not a lienable owner under the mechanics' lien acts. See text accompanying note 93 supra. This question is largely unlitigated. See Note, 19 BrookLyN L. REv. 287 (1953). In a few jurisdictions trust property has been specifically exempted from vulnerability to mechanics' liens. See, e.g., PA. Star. Anv. tit. 49, § 22 (1930).

110. For an excellent discussion of the various licensing statutes, see Edwards, Legal Requirements That Building Contractors Be Licensed, 12 LAW \& ContEMr. ProB. 76 (1947).

The following states require licensing of general contractors undertaking any private work within the state: Arizona, Delaware, Florida, Nevada, New Míexico, North Dakota, and Vermont. The following impose license requirements for work valued at a certain minimum or above, the minimum figures ranging from $\$ 5,000$ to $\$ 20,000$ : Alabama, California, Maryland, Mississippi, South Carolina, Tennessee and Utah. Arkansas and Virginia require licensing only if the project exceeds $\$ 20,000$. BUREAU of ConTract INFonaration, Inc., Summary of State Regulations and Taxes Affecting General ConTRACTORS (1956). For statutes compelling the licensing of subcontractors, see note 113 infra.

111. For legislation governing state projects, see, e.g., Miss. CODE ANN. $\S \S 8968-01$, -15 (1956) ; N.J. Stat. ANn. \$ 40:50-5 (1940) ; ORE. Rev. Stat. \$\$ 279.010, .016 (1953); PA. Rev. Stat. tit. 71, $\$ 642$ (1942). Analogous municipal regulations are upheld only when the prequalification of bidders system is administered objectively. See, e.g., Harris v. City of Philadelphia, $299 \mathrm{~Pa} .473,149$ Atl. 722 (1930); cf. Araneo-White Constr. Co. v. Joint Municipal Sewer Comm'n, 9 N.J. Misc. 243, 154 Atl. 313 (Ch. 1931). According to a 1.945 survey, most municipalties do not have a standard prequalification system. Rhyne, Munictpal Contracts 69 (1952).

112. E.g., Ala. Code Ann. tit. 46, § 66-82 (1940); ArIz. Code Ann. § 67-2302 (Supp. $1952)$; Cal. Bus. \& Prof. Code $\$ \$ 7000-145$ (1955); Fra. Stat. ANn. $\$ 205.35$ (1943); Nev. Rev. Stat. \$\$ 624.230-.320 (1956); TenN. Code AnN. $\$ \S 62-601,-602$ (1955).

113. See, e.g., Ill. Ann. Stat. ch. 1111/2, § 116.48 (Smith-Hurd 1954) (plumbers); Mo. ANn. Cone art. 56, $\$ \$ 179,180$ (1957) (plumbers, gas-fitters, etc.) ; N.C. GEN. STAт. ANN. \$ 87-10 (general contractors), \& 87-22 (plumbers), \$ 87-34 (tile), \& 87-44 (electrical 
Although licenses run for a limited number of years, renewal is practically automatic in most instances, provided a fee is paid. The submission of current data is rarely demanded. ${ }^{114}$ But even were renewal contingent on up-to-date information, the rapidity with which conditions change in the industry would prevent licensing from ensuring the solvency of contractors. A license based on an analysis of a contractor's financial position at a given time is no guarantee that he will be able to complete even his immediate undertakings successfully. To be effective, a licensing system would have to provide for a continual inquiry into every contractor's commercial fortunes-an administratively unfeasible task. It would be politically unfeasible as well, for state trade associations with large, vested interests are, in the main, responsible both for the promulgation and enforcement of the licensing acts. ${ }^{115}$ The screening of applicants is often directed not at incompetence and financial instability but at firms desiring to introduce new and efficient building techniques or simply to engage in vigorous competition. Inherent difficulties of this sort, combined with the legislature's disinterest, will continue to frustrate efforts looking to the adequate disclosure of information.

Aside from the disclosure provisions, many licensing statutes further require that every licensee deposit a surety bond with the licensing agency. Invariably small, the amount of the bond frequently does not exceed $\$ 500$ or $\$ 1,000$.116 Licensees who have made such deposits commonly advertise themselves as "bonded," and thus engage in a practice which has proved highly deceptive. Owners purchasing a licensee's services are often unaware of the insignificance of his bond, and assume a security which does not exist. Hence, bonding as an adjunct of licensing might well be abolished-unless bonds reasonably large in amount are required, or inadequately secured licensees are forbidden to hold themselves out as "bonded."

\section{BoNDING}

Almost unknown in the days when the first mechanics' lien statutes were passed, the corporate surety has taken on an increasingly important role in

work) (1949) ; VA. Code ANN. $\$ \$ 58-297,-303.1$ (1955), § 58-299 (Supp. 1958) (electricians, plumbers, steam fitters; sellers of tombstones specifically excluded).

114. For renewal provisions, see, e.g., the statutory sections cited in note 113 supra.

115. An unusual statutory acknowledgement of the power of trade associations was once found in IrL. ANN. STAT. \$ 103-13 (1944) (later amended), which directed that the Board of Plumbing Examiners be chosen only after the recommendations of the Illinois Master Plumbers' Association and the Illinois Association of Journeymen Plumbers and Steam Fitters had been given "due consideration." At one time in North Carolina, every member of the Tile Licensing Board, was also a member of the Tile and Mantel Contractors Association of America. Tile \& Mantel Contractors Ass'n, Convention Proceedings 81 (1938). See generally Edwards, Legal Requirements That Building Contractors Be Liccissed, 12 LAW \& ConteMr. Prob. 76 (1947).

116. See, c.g., Minn. Stat. AnN. $\$ \S 326.25-26$ (1947). 
the building industry. ${ }^{117}$ In contrast with the limited objective of the lien statutes-to allocate losses among the persons on whom they naturally fall-the policy behind surety bonding is both to minimize losses and to distribute them over the entire industry. Rather than allow unpaid claims to accumulate against and endanger the project, bonding ensures the owner that no such claims will arise and that the improvement will be finished on time and for the contract price. This protection arises through two different and distinct kinds of bonds which are usually furnished by the general contractor as principal.

The Performance Bond. The first type of bond guarantees that the contract will be performed in accordance with its provisions. ${ }^{118}$ Since most contracts make the payment of subcontractors and suppliers a definite element of performance, the bond's protection extends to lien claimants as well as to the owner. ${ }^{119}$ On a default by the general contractor, the owner may complete the project himself and charge the surety with the difference between the final cost and the contract price-within the limits of the surety's liability as set by the penal sum of the bond.120 The bond often contains an additional provision under which the surety may elect, with the owner's permission, to take over the task of completion either personally or by reletting the job. ${ }^{121}$ So electing, a surety may have the supplemental right to make use of the general contractor's equipment and materials. Absent a default, the surety is usually authorized

117. See generally BackMan, Surety Rate-Making 1 (1948).

According to figures furnished the Yale Law Journal by the Surety Association of America, the premiums written (received) and losses incurred on surety bonds on construction projects in recent years have been as follows.

Contract Bond Experience of Approximately Fifty Surety Conpanies 1951-1956

\begin{tabular}{lccrrrrr}
\hline \hline & \multicolumn{2}{c}{ Federal Contracts } & \multicolumn{2}{c}{ Nonfederal Contracts* } & \multicolumn{2}{c}{ Total Contracts } \\
& Premiums & Losses & Premiums & Losses & Premiums & Losses \\
& Written & Incurred & \multicolumn{1}{c}{ Written } & Incurred & \multicolumn{1}{c}{ Written } & Incurred \\
\hline 1951 & $\$ 21,124,877$ & $\$ 5,746,698$ & $\$ 60,674,219$ & $\$ 27,871,209$ & $\$ 81,799,906$ & $\$ 33,617,907$ \\
1952 & $21,431,462$ & $5,369,537$ & $64,559,579$ & $21,058,049$ & $85,991,041$ & $26,427,586$ \\
1953 & $16,125,444$ & $8,497,871$ & $75,879,484$ & $21,910,320$ & $92,004,928$ & $30,408,191$ \\
1954 & $14,381,336$ & $9,505,795$ & $81,576,837$ & $22,180,022$ & $95,958,173$ & $31,685,817$ \\
1955 & $16,417,365$ & $9,252,341$ & $86,575,731$ & $34,475,182$ & $102,993,096$ & $43,727,523$ \\
1956 & $16,303,032$ & $10,275,393$ & $91,327,971$ & $44,004,936$ & $107,631,003$ & $54,280,329$ \\
\hline \multicolumn{2}{l}{ Total $\$ 105,783,516$} & $\$ 48,647,635$ & $\$ 460,593,821$ & $\$ 171,499,718$ & $\$ 566,377,337$ & $\$ 220,147,353$
\end{tabular}

*The Surety Association of America estimates that $75 \%$ of the nonfederal contract totals represent state and local government projects; the remainder, private building.

118. See Surety Ass'n of Aderica, Construction-The Bonded Contract is the OWNER's PROTECTION 18 (1957).

119. See Parker \& Adaris, The A.I.A. Standard Contract Fordis and the Law 40 (1954).

120. This term refers to the sum fixed in the bond as the maximum of the surety's liability. See, e.g., CrIst, Corporate Suretyship 114 (1939).

121. See Surety Ass'n of America, Construction-The Bonded Contract is the OWNer's Protection 14 (1957). 
to inspect the general contractor's operations and to exercise various controls designed to forestall financial difficulties and departures from the contract. A collateral agreement may permit the surety to intervene and manage the project through new supervisory personnel, should the general contractor encounter difficulties with which he is unable to cope. ${ }^{122}$

When default occurs and the owner has been reimbursed, a secondary right of action against the surety is sometimes allowed subcontractors and suppliers under a third-party beneficiary theory. ${ }^{123}$ As a practical matter, the principal protection that these claimants derive from the performance bond is its assurance that the project will not be discontinued because of the default of the general contractor-and that they will therefore eventually be paid. Since a take-over by the surety of a bonded owner normally follows a default more promptly than does an unbonded owner's effort to complete a project, bonding tends to ensure a greater continuity of employment to those subcontractors whose performance warrants their retention.

The Payment Bond. The principal source to which the subcontractor will look for immediate satisfaction is the payment bond-a specific guarantee of reimbursement for all labor and materials. It usually gives the unpaid subcontractor or supplier a direct right of action against the surety and is customarily in a sum approximating fifty per cent of the contract price. ${ }^{124}$ Phrased in terms sufficiently broad to eliminate practically any uncertainty over what claims are covered, this type of bond avoids the litigious quibbling so common under the lien statutes.

\section{Bonding on Public Works}

To date, both kinds of contract bonding have been utilized primarily in the field of public works. ${ }^{125}$ This development stems from the fact that, while mechanics' liens may sometimes attach to the fund due on public works, ${ }^{120}$ they may never attach to the public improvements themselves. ${ }^{127}$ Recognizing

122. For a detailed discussion of what the surety may do to bail out a sinking general contractor, see Mansfield \& McCahan, Clains Under Contract Bonds, 21 INs. Counsed J. 265 (1954).

123. See Croker v. N.Y. Trust Co., 245 N.Y. 17, 156 N.E. 81 (1927) ; cf. Buffalo Cement Co. v. McNaughton, 90 Hun. 74, 35 N.Y. Supp. 453 (Sup. Ct. 1895), aff'd, 156 N.Y. 702, 51 N.E. 1089 (1898).

124. For sample form of bond, see Surety Ass'n of America, Construction-THe Bonden Contract is the Owner's Protection 16 (1957).

125. See Gaffney, Suretyship for Construction, Casualty \& Surety J., Nov. 1955, p. 15.

In addition to taking out a payment and/or performance bond on being awarded a contract, the general contractor is usually required to take out a bid-bond on submitting his bid. This bond guarantees that, if selected, he will enter the contract. See, e.g., Palo \& Dodini v. City of Oakland, 79 Cal. App. 2d 739, 180 P.2d 764 (Dist. Ct. App. 1947); Reyne, Municipal Contracts 53 (1952).

126. See, e.g., N.Y. Lien Law § 5; N.J. Stat. AnN. § 2A:44-128 (1952) ; Tex. Rev. Civ. Stat. Ann. art. 5472(a) (1948).

127. Neal-Millard Co. v. Trustees of Chatham Academy, $121 \mathrm{Ga} .208,48$ S.E. 978 
a responsibility to safeguard its subcontractors and suppliers, ${ }^{128}$ the federal government requires, under the Miller Act, that general contractors supply both performance and payment bonds on any contract worth over $\$ 2,000.120$ The amount of the performance bond is not specifically set by the statute, but is left to the governmental instrumentality letting the contract. ${ }^{130}$ On the other hand, the limits of the payment bond are defined in the act as half the contract price on projects costing less than $\$ 1,000,000$, and slightly less than half for larger projects. ${ }^{131}$ The right to sue on a payment bond is limited to those contracting directly with the prime contractor or with his immediate subcontractors or suppliers. Since the right of recovery is denied persons lower down the contractual chain, the government often insists that the general contractor require the subcontractors to bond themselves in turn. ${ }^{132}$ In this fashion, coverage is extended to virtually every potential claimant, and the available fund for all claimants is increased.

The Miller Act's performance and payment bonds comprehend a variety of claims which do not ordinarily give rise to statutory liens. ${ }^{133}$ The average bond is phrased in terms of discharging the "claims arising" on a project and, unlike many of the lien statutes, does not enumerate the specific items and classes of work which it covers. Since a bond's language usually embraces any claim

(1904) ; Knapp v. Swaney, 56 Mich. 345, 23 N.W. 162 (1885) ; School Dist. No. 27 v. Graham, 45 Okla. 531, 146 Pac. 213 (1915) ; Annot., 26 A.L.R. 326 (1923).

The single exception to this rule is the state of Maine's special enactment of 1915, which allows mechanics' liens to attach to public improvements and subjacent land. ME. Rev. Srat. ch. 178, $\$ 34$ (1954). Maine has no bonding regulations covering public works.

128. National Sur. Corp. v. United States, 132 Ct. Cl. 724, 133 F. Supp. 381, cert. dentied, 350 U.S. 902 (1955). See also Liebman v. United States ex rel. California Elec. Supply Co., 153 F.2d 350 (9th Cir. 1946).

129. 49 Stat. 793 (1935), 40 U.S.C. $\$ \S 270(a)$-(c) (1952). The Miller Act replaced the Heard Act, 28 Stat. 279 (1894), which had proved insufficient to cope with increasingly complex contract situations. See Stickells, Bonds of Contractors on Federal Public Worlss: The Miller. Act, 36 B.U.L. Rev. 499 (1956) ; Cushman, Surety Bonds on Federal Construction Contracts: Current Decisions Reviewed, 25 FoRDHAM L. REv. 241, 242 (1956).

130. For example, performance bonds obtained on contracts let by the Army procurement program must be in a penal sum of at least $50 \%$ of the contract price. If change orders (modifications) in excess of $\$ 25,000$ are entered, the penal sum must be raised. CREDIT Manual of Conmerctal Laws 571 (1957).

131. On contracts not over $\$ 5,000,000$ but in excess of $\$ 1,000,000$ the bond must equal $40 \%$ of the price. On contracts exceeding $\$ 5,000,000$, the bond must be in the sum of $\$ 2,500,000$. Certain departments of the federal government may waive the Miller Act with respect to cost-plus, fixed-fee and similar contracts for public works. Miller Act, 49 Stat. 793 (1935), 40 U.S.C. $\$ 270$ (a) (2) (1952).

132. Miller Act coverage has been specifically extended to labor and material suppliers of the first degree. Basich Bros. Constr. Co. v. United States ex rel. Turner, 159 F.2d 182 (9th Cir. 1946) ; United States ex rel. Harrington v. Trione, 97 F. Supp. 522 (D. Colo. 1951). Suppliers of the second degree, however, cannot recover on the payment bond. Clifford F. MacEvoy Co. v. United States ex rel. Calvin Tomkins Co., 322 U.S. 102 (1944).

133. Claims recoverable under the Miller Act are not limited to those ordinarily giving rise to liens. See, e.g., Brogan v. National Sur. Co., 246 U.S. 257 (1918) ; cf. United States ex rel. Samuel Hastings Co. v. Lowrance, 252 Fed. 122 (8th Cir. 1918) (Heard Act). 
which is a reasonable consequence of work on the project in question, the mechanics'-lien confusion over what items are lienable is generally avoided.134

State and municipal improvements are also exempt from mechanics' liens. ${ }^{135}$ Most states have, in one way or another, followed the pattern set by the federal government, and require payment or performance bonds, or both. ${ }^{136}$ The same persons who are protected by the terms of the Miller Act are normally covered by the corresponding provisions of local regulations. ${ }^{137}$ A number of the states have simply adopted the federal, two-bond system, ${ }^{138}$ but most require only a single bond which provides both guarantees, more or less. ${ }^{139}$ In contrast with the separate payment bond, however, the composite bond prefers the owner over subcontractors and suppliers. As a result, a claimant may be unable to recover anything because the owner's charges have exhausted available funds. ${ }^{140}$

Some jurisdictions, including New York, require that each bond claimant be eligible for a mechanic's lien, and compel claimants to go through the motions of establishing in court their right to a lien before recovering against the surety. ${ }^{141}$ This absurd procedure defeats the advantages of bonding, which

134. See, e.g., Glassell-Taylor Co. v. Magnolia Petroleum Co., 153 F.2d 527 (5th Cir. 1946) (construing Miller Act bond).

135. See cases cited note 127 supra.

136. Credit Manual of Commerctal Laws $592-667$ (1958). Only Kentucky, Maine and South Carolina lack express surety bond legislation for public works. Their highway departments nevertheless require labor and material bonds. Haas, The Corporate Surety and Public Construction Bonds, 25 Geo. WASH. L. REv. 206, 207 n.5 (1957). States requiring a bond in an amount not less than $50 \%$ of the contract price are: Alabama, Arizona, Colorado, Louisiana, Massachusetts, New Mexico, Ohio, Pennsylvania, RhodeIsland, and Wyoming. A bond of not less than $75 \%$ of the contract price is required in Delaware and Iowa; $80 \%$ is the lower limit in New Hampshire. The bond must equal $100 \%$ of contract price in: Arkansas, Connecticut, District of Columbia, Georgia, Idaho, Indiana, Kansas, Maryland, Minnesota, Nebraska, Nevada, New Jersey, North Dakota, Oklahoma, South Dakota, Virginia, Washington and Wisconsin. Sliding scales similar to those of the Miller Act control in California, Illinois, North Carolina, Tennessee and West Virginia. The remaining states have no express statutory requirement, the sum of the bond being determined at the discretion of the governmental body concerned.

Many municipalities have also adopted mandatory bonding requirements. RHYNE, Municipal Contracts 53-55 (1952).

137. A position contrary to that of the Miller Act with respect to the rights of firstdegree suppliers prevails in some states. E.g., Fosmire v. National Sur. Co., 229 N.Y. 44, 127 N.E. 472 (1920). See Note, 23 Sr. JoHN's L. REv. 315 (1949). If the subcontractor has himself obtained the bond, the supplier's rights may be different. Daniel-Morris Co. v. Glens Falls Indem. Co., 308 N.Y. 464, 126 N.E.2d 750 (1955).

138. E.g., Ala. Code ANn. tit. 50, § 16 (1940) ; Cal. Gov't Code $\$ \$ 4200-08$ (1955); Conn. Gen. Stat. $\$ 7214$ (1949); Vt. Stat. $\$ 4909$ (1947); Wis. Stat. $\$ 289.16$ (1955). 139. CRedit Manual of Commareial Laws 592-697 (1958).

140. See Van Clief \& Sons v. City of New York, 141 Misc. 216, 252 N.Y. Supp. 402 (Sup. Ct. 1931) ; cf. Fosmire v. National Sur. Co., 229 N.Y. 44, 127 N.E. 472 (1920); Buffalo Cement Co. v. MrNaughton, 90 Hun. 74, 35 N.Y. Supp. 453 (Sup. Ct. 1895).

141. "In order to secure any rights and benefits conferred herein, laborers having claims for unpaid wages ... shall file and enforce a mechanics' lien pursuant to the provisions of the lien law, and a materialman, in order to secure any such rights and benefits, shall file and enforce a mechanics' lien pursuant to the provisions of the lien law." N.Y. 
largely arise from the elimination of the difficulties and ambiguities inherent in lien actions. Making a bond-recovery action contingent on the proof of a valid, hypothetical lien has nothing to recommend it and should be superseded by a rule allowing direct recourse to the surety.

\section{Bonding Private Projects}

Proposals for the statutory extension of bonding to private construction received some measure of support in 1932, when a committee sponsored by the United States Department of Commerce drafted the Uniform Mechanics' Lien Act. The model statute would enable an owner to exempt his property from liens if he had required that the general contractor obtain adequate bonding. ${ }^{142}$ This provision is largely academic, for the act itself has been cordially ignored. ${ }^{143} \mathrm{~A}$ few states, however, have analogous legislation permitting owners voluntarily to substitute bond protection for mechanics'-lien liability. ${ }^{144}$

Although the efficacy of permissive statutes of this nature is difficult to gauge, they probably afford little protection to the subcontractor or supplier. Their flaw is basic. When initiated industry-wide, bonding serves to apply the corporate sureties' investigation experience in such a way as to eliminate the bad credit risk. But if the system is merely permissive, the contractor who is unable to secure a bond will continue to operate under the lien law. Owners may, of course, refuse to accept him without adequate bonding, but other economic considerations, such as a significantly low bid, could induce an owner to forego the protection of a bond. The natural optimism of many owners at the outset of a project, and their tendency to minimize risks when faced with the added expense of a bond, ${ }^{14 \bar{s}}$ make unlikely their insistence on the guarantees of suretyship..$^{146}$

STATE FIN. LAW $\$ 137$. The statute has been amended to provide that if a lien would be invalid because of the insufficiency of the "amount due," the claimant may still recover from the surety if the lien be otherwise valid. N.Y. STAT. Fin. LAw $\$ 137$ (Supp. 1958).

For general background, see N.Y. LAw Revision Comrar, 1945 Report, ReCOMMIENDATIONS AND STUDIES 579 (1945).

142. Uniform Mechanics' Lien Act $\$ 7$ (1932).

143. See Imlay, Problems in Uniform Mechanics' Lien Act, 19 A.B.A.J. 116 (1933) (written by the chairman of the Mechanics' Lien Act Committee, National Conference of Commissioners on Uniform State Laws) ; Legislation, 19 VA. L. REv. 406 (1933). For draft legislation proposed, see Comment, Sixth Tentative Draft of a Uniform Mechanics' Licn Statute, 41 Y ALE L.J. 271 (1931) ; Cushman, The Proposed Uniform Mechanics' Licn Lazu, 80 U. PA. L. Rev. 1083, 1086, 1088 (1932).

144. The Uniform Mechanics' Lien Act was adopted, in substance, by one state. Fla. Stat. ANn. $\$ \$ 84.01-35$ (1943). A few other states have variants of $\$ 7$ of the uniform act. See, e.g., CaL. Civ. Proc. Code $\$$ 1181-96.1 (1955); N.Y. LIEN LAw $\$ 37$.

145. The general rates on contract bonds have been reduced by some 25 to $331 / 3 \%$ from 1936 to 1948. See Backman, Surety Rate-Making 302 (1948). Since then, total premium costs have been reduced still further. A general maximum rate of $1 \%$ prevailed until 1955 for a 24 month bond, with the usual rate being $\$ 7.50$ per $\$ 1,000$ for contracts less than $\$ 2,500,000$. The present rates are $\$ 10$ per $\$ 1,000$ for the first $\$ 100,000, \$ 6.50$ per $\$ 1,000$ for the next $\$ 2,400,000$ and so on down to $\$ 4.70$ per $\$ 1,000$ for any amount in excess of 
Some private work is being bonded, however, thanks to the responsible exercise of independent judgment. The bulk of such bonding appears to cover comparatively large building projects-which are commonly undertaken by reputable, responsible and heavily capitalized organizations. Thus, from the subcontractor's point of view, private bonding prevails where protection is least needed. It is the seventy per cent of general contractors who are small operators, those with three or fewer employees in their offices, who pose the major threat to the unwary. ${ }^{147}$

When guaranteed by a surety, private construction normally is covered by both performance and payment bonds. The dual-bond arrangement provides owner, subcontractor and supplier with a measure of protection not available under the lien system. A general contractor who obtains a bond has, in effect, met qualification standards which reflect both the surety's experience in judging underwriting risks and his records relating to the past performance of contractors. Although a surety may occasionally seek to increase his business by underwriting risks refused elsewhere, frequent recourse to this practice has, in the past, invariably led to the surety's insolvency. In brief, since sureties are unlikely to bond a contractor on a job for which he is not equipped, potential defaults can be avoided and small contractors can be restricted to projects which do not overextend their limited capital. If a general contractor is unable to take on a given project alone, the surety may refuse to bond him until he joins forces with another contractor. The surety may even take an active part in the formation of such joint ventures, which not only consolidate resources but also increase the number of responsible bidders. ${ }^{148}$ Of course, by successful performance a small contractor can increase his capital to the point where, by himself, he is able to secure bonding for the larger projects previously closed to him.

The presence of the surety tends to shorten the interval between the submission and acceptance of a bid, since the qualifications of a bonded low bidder do not require extensive re-examination. The flow of materials is also ex-

$\$ 7,500,000$. Thus, a 24 -month bond for a $\$ 2,500,000$ contract, which would have cost $\$ 18,750$ at the pre-1955 rate, now costs $\$ 16,600$. Surety Ass'N of AMrerica, Rate Manual of FideitTy, ForgenX AND SuRETy Bonds, temporary page C-9 (July 20, 1955). This compares with a rise in material prices in the construction industry of $172 \%$ since 1939 , a rise of $152 \%$ in construction machinery prices and a rise of $243 \%$ in common labor wages. See Engineering News Record, Feb. 13, 1958.

146. Furthermore, under the laws of 26 jurisdictions an owner has little incentive to take out a bond initially, since he can replace a lien, once it attaches, with a bond or other security or undertaking. The jurisdictions are: Arkansas, California, Connecticut, District of Columbia, Florida, Indiana, Iowa, Kansas, Kentucky, Louisiana, Maine, Massachusetts, Michigan, Mississippi, Nebraska, New Hampshire, New Jersey, New York, North Dakota, Oregon, Tennessee, Texas, Utah, Washington, West Virginia and Wyoming.

147. For the prevalence of small contractors, see Haas, The Corporate Surety and Pubic Construction Bonds, 25 Geo. WAsH. L. Rev. 206, 207 (1957).

148. Cushman, Surety Bonds on Federal Construction Contracts: Current Decisions Revicued, 25 FordhaM L. Rev. 241, 253 (1956). 
pedited, because fears of poor credit risks need not inhibit materialmen. In fact, the added protection of bonding serves to induce more bids, so that competition among subcontractors and suppliers is increased. Furthermore, their bids will reflect the prospect of prompt reimbursement and hence will not incorporate loading charges to cover the hazard of nonpayment. ${ }^{149}$ The consequent reduction in construction costs could offset the expense added by bond premiums.

\section{ConClusion}

In almost every respect, the statutory mechanic's lien provides protection inferior to that afforded the owner, the general contractor, the subcontractor and the supplier by an adequately arranged bonding system. ${ }^{150}$ Comparatively speaking, the presence of the corporate surety reduces both the size of the ultimate loss and its incidence on any individual party. The frequent imprudence or shortsightedness of owners nonetheless renders the mere availability of bonding insufficient to ensure its use in a uniform and consistent manner. A need for statutory compulsion of some sort is definitely indicated. Bonding should either be mandatory, or the owner's liability under existing lien law should be so increased as to leave him no practical alternative but to require the bonding of his general contractor.

The better solution would be to make bonding a prerequisite to engaging in private construction activities of any significance. State legislation to this end could be patterned after the provisions of the Miller Act, although the minimum value of a contract which would invoke such a statute might well be raised from the Miller Act figure of $\$ 2,000$ to at least $\$ 10,000$. Contracts worth less than $\$ 10,000$ generally are performed within a relatively short period, with payment made in one lump sum rather than in installments. And, obviously, $\$ 2,000$ no longer represents a project of the size that it did when the act was passed in 1935. Moreover, the present lien laws could be retained to provide remedies on projects which involve less than the statute's minimum contract price.

Any statute making surety arrangements mandatory should set forth a model bond whose terms would automatically meet the law's requirements. As in the Miller Act, a schedule of minimum bonding sums for corresponding contract prices should also be included. ${ }^{151}$ To protect the surety, such legislation should avoid the loopholes in present bonding acts. They permit a contractor or supplier who has been lax in pursuing his claim to reactivate the statutory period for notifying the surety by performing a token service long

149. See ibid.

150. See Brooke, Other People's Labor and Material in the Bullding Industry OF GREATER NEW YORK (1933) (entries of 33,117 recorded liens covering private improvements studied over a six-year period; during every year at least half of the recorded liens were left unsatisfied).

151. For the Miller Act schedule, see 49 Stat. 793 (1935), 40 U.S.C. $\$ 270$ (a) (1952). 
after completion of the work giving rise to the claim. ${ }^{152}$ Enforcing strict compliance with the period for filing claims should work no hardships, especially if future statutes require the surety to inform all subcontractors and suppliers of the time limits on their rights.

Preferably, the general contractor's payment bonds should cover all subcontractors and immediate suppliers. If, however, coverage is restricted, subcontractors should be compelled to obtain surety protection against the claims of those not within the scope of the primary bond. In addition, a contractor or owner who deliberately or negligently fails to meet the requirements of the statute might be held personally liable to any injured claimant.

A statute imposing mandatory bonding, though an inhibition on freedom of contract, would undoubtedly be constitutional. ${ }^{153}$ State legislatures may nevertheless find a law of this sort too radical a departure from their current mechanics' lien provisions. ${ }^{154}$ In this event, another, though less desirable, legislative route is available.

152. See, e.g., United States for use and benefit of General Elec. Supply Corp. v. Hershson, 52 F. Supp. 832 (S.D.N.Y. 1943) ; cf. In re Abbot-Gamble Co., 195 Fed. 465 (2d Cir. 1912); Nelson v. Schrank, 273 App. Div. 72, 75 N.Y.S.2d 761 (1947).

153. While U.S. CoNST. art. $10, \S 10$ has been read as a general prohibition against interference with the right to contract, the seriousness with which this prohibition is regarded has diminished greatly since the days of Mr. Justice Peckham. Ultimately, the question is one of whether or not the state's economic interests justify the exercise of the police power notwithstanding the interference with contract that may occur. See, e.g., Home Bldg. \& Loan Ass'n v. Blaisdell, 290 U.S. 398 (1934). The same argument is at the root of any attack based on the due process clause of the fourteenth amendment. People v. Levitt, 145 Misc. 621,260 N.Y. Supp. 458 (N.Y.C. Magis. Ct. 1932).

State regulation of the construction industry has been sustained on analogous questions. The trust fund provisions in New York, N.Y. LIEN LAw \& 36 (Supp. 1958), were challenged on constitutional grounds; the statute was sustained in the following language:

The evils which infested the building industry are well known to all. It is common knowledge that "shoestring" builders, contractors and subcontractors frequently engaged in building enterprises with little or no capital; that contracts were made by them for material and labor; that payments subsequently received by such builders ... were frequently not applied to the payment of such material and labor, but instead were diverted from their proper purpose, leaving to the victims only the remedy of a mechanic's lien without the security of a fund out of which it could be satisfied.

It is easily seen how such transactions are affected with a public interest. Losses incurred must be absorbed by the general public. This results in higher construction costs and therefore in higher rents. The cost of construction is eventually paid by the public....

People v. Levitt, supra at $622-23,260$ N.Y. Supp. at 460.

154. An example of the pressure to which legislatures will be subjected is found in the experience of interested citizens who attempted in 1946 to secure revision of N.Y. State FIN. LAw $\& 137$, which links recovery on a surety bond given on a public contract with the proof of a valid mechanic's lien. Reportedly, the proposed change would have been enacted but for the objection of a person in the state department in charge of mechanics' liens whose job would have been eliminated. 
A modification of the Pennsylvania or direct-lien system could achieve approximately the same results as a mandatory bonding statute. On the assumption that the general contractor is essentially the owner's agent for procuring the labor and materials used on a project, the owner's property could be subjected to all subcontractors' and suppliers' liens without limitation. Hence, the contract price would have no effect on the owner's total liability, and statutory provisions immunizing the owner from any contractual claims until all work is done could be repealed as needlessly restrictive, for the owner would no longer be able to limit his total lien and contract payments to the contract price. In addition, waivers of lien rights and owners' disclaimers would of necessity have to be disallowed. Finally, the owner should become personally liable for all lien claims not satisfied by foreclosure on the property in question. ${ }^{\text {tat }}$ In the case of corporate owners whose assets are limited to the project under construction, imposing personal liability on the directors may also be necessary. If the general contract was let by one not the owner of the fee, liability should be imposed on the contracting, apparent owner.

Incorporating the foregoing provisions into direct-lien statutes would make it virtually essential that every owner require his general contractor to procure a bond. The liability imposed by the revised lien law would probably dictate the form and amount of the bond. Astute statutory draftsmanship could force the owner to demand bonding which would protect all claimants however far removed, or to demand that the general contractor impose surety arrangements on his subcontractors, as occurs under the Miller Act. ${ }^{150}$

Mandatory bonding, whether imposed directly by statutory prescription or indirectly through the owner's unlimited mechanics'-lien liability, may appear at first a drastic proposal. Patching up existing lien acts is, however, an unsatisfactory alternative. Admittedly, the classes of persons entitled to lien and

155. Personal liability as a result of failure to bond has already been imposed in a few jurisdictions, and the constitutionality of such provisions upheld. UTAF CODE ANN. \$\$ 14-2-1, 14-2-2 (1953), Rio Grande Lumber Co. v. Darke, 50 Utah 114, 167 Pac. 241 (1917) ; LA. Rev. Srat. Ann. \$\$ 9.4802-.4806 (1950), Arcadia Lumber Co. v. Austin, 15 La. App. 212, 131 So. 601 (1930), Utley Paint Co. v. Foster, 1 La. App. 27 (1924) ; cf. Standard Acc. Ins. Co. v. Bear, 134 Fla. 523, 184 So. 97 (1938).

The Utah statute requires that the owner of any project over $\$ 500$ in value obtain a bond in the amount of the contract price, conditioned on both performance and the payment of those who supply labor and materials to the improvement. Failure to obtain the bond renders the owner personally liable to all such persons. A similar statute is now under consideration in Colorado. See Colo. Reg. Sess. 1957, S.B. 230 (for the form in which the latest proposal, rather emasculated, has reached the legislature). The Utah personal liability provision has been opposed in Colorado on the ground that, by eliminating the security of the improvement, it unwisely exposes subcontractors to the difficulties of collecting in a purely personal action. Letters in the files of The Surety Association of America. This objection is founded on a misunderstanding. The Utah code still provides for mechanics' liens, UTAF CODE ANN. \$ 38-1-3 (1953), and \$\$ 14-2-1 and 14-2-2 have been specifically held to be supplementary to the mechanic's lien, not replacements of it. Rio Grande Lumber Co. v. Darke, supra.

156. See text at note 132 supra. 
the types of lienable claims could be enlarged, but fundamental shortcomings would remain. The lien system presupposes the existence of construction losses and merely provides a method of allocating them among the parties immediately involved. Absent a surety, it is only at the direct expense of the owner that lien protection can be extended for subcontractors and suppliers; and restricting lien protection obviously leaves them to their own devices amidst the manifold hazards of a highly speculative industry. Bonding alone accords subcontractors and suppliers maximum security without subjecting owners to a crushing burden of potential liability. Losses sustained on a bonded project are borne initially by all the general contractors who pay premiums to the surety companies. Moreover, where bonding is conventional, premiums constitute a construction expense which is reflected in every contractor's bid. The owner who accepts a bid may be expected to pass the premium costs on to the ultimate users of the particular project. Thus, the price of added stability in the construction industry will actually be paid by those who ultimately benefit. 